\title{
Keskustelukumppanin kehuminen suomalaisessa keskustelussa
}

\author{
Marja Etelämäki, Markku Haakana ja Mia Halonen
}

\section{Johdanto}

Tässä artikkelissa analysoimme yhtä vuorovaikutuksen affektista puhetoimintoa, vastaanottajan kehumista suomenkielisissä keskusteluissa (puhetoiminnoista ja affektista yleisemmin, ks. esim. Sorjonen \& Peräkylä 2012; ISK 2004: \$1707; Ochs \& Schieffelin 1989). Tarkastelemme erityisesti sitä, millaisia kehut ovat rakenteeltaan, miten ne otetaan vastaan ja millaisia funktioita niillä on. ${ }^{1}$ Kehumisella tarkoitamme vastaanottajaan tavalla tai toisella kohdistuvaa myönteistä arviota. Kehuttavana voi olla esimerkiksi puhekumppanin luonne, ulkonäkö, hänen toimintansa tai jokin omistamansa (esim. vaatteet tai asunto). Olemme siis lähteneet varsin väljästä kehun määritelmästä ja keränneet tällaisen vuoron sisältäviä jaksoja erilaisista keskusteluaineistoista. Tutkimuksemme on metodiltaan keskustelunanalyyttinen, eli tarkastelemme kehumista toimintana, jonka muotoutumiseen vaikuttaa myös se, miten vastaanottaja käsittelee kehulta vaikuttavaa vuoroa. Metodisesti yksi vaihtoehto kehun tunnistamiseksi olisi ollut nojautua pelkästään vastaanottajan tulkintaan: olisimme voineet poimia aineistosta ne myönteiset arviot, joita vastaanottaja käsittelee kehuina (kehun rajaamisesta ks. Shaw \& Kitzinger 2012). Tällöin olisi kuitenkin pitänyt tietää ennalta, miten kehuja otetaan vastaan. Lisäksi keskustelun vuorot ovat usein monitulkintaisia ja saattavat tarjota vastaanottajalle erilaisia mahdollisuuksia reagoida. Tähän monitulkintaisuuteen emme olisi päässeet käsiksi, jos olisimme poimineet aineistosta vain ne vuorot, joita vastaanottaja selvästi käsittelee kehuina.

Keskustelunanalyyttisesti kehuja on analysoitu vain muutamassa tutkimuksessa: Pomerantz (1978) on tutkinut kehuja ja niiden vastaanottoa amerikanenglantilaisessa ja Golato (2005) saksankielisessä arkikeskustelussa. ${ }^{2}$ Suomenkielisen arkikeskustelun ke-

1. Analyysit, joihin artikkelimme perustuu, on tehty yhdessä, ja nimemme ovat sukunimien mukaisessa aakkosjärjestyksessä. Artikkelia kirjoittaessamme olemme kuitenkin keskittyneet kehujen tarkastelussa eri asioihin: Marja Etelämäki vastaa pääasiassa kehujen rakennetta, Mia Halonen kehujen vastaanottoa ja Markku Haakana kehun paikkaa ja funktioita käsittelevästä osiosta.

2. Kehuja on tutkittu myös muutamista institutionaalisista vuorovaikutustilanteista: Svinhufvud (2011) tarkastelee opponentin kehuvia lausumia graduseminaarissa, Gathman, Maynard ja Schaeffer (2008) haastatteluvuorovaikutuksessa ja Shaw ja Kitzinger (2012) kotisynnyttäjien auttavassa puhelimessa. 
huja ei ole aiemmin systemaattisesti tutkittu; Tainion kannanottoja käsittelevissä tutkimuksissa $(1993,1997)$ tarkastellaan kuitenkin myös muutamia kehutapauksia. Kehuista on olemassa runsaastikin kansainvälisiä pragmaattisia ja diskurssianalyyttisiä tutkimuksia (esim. Wolfson \& Manes 1980; Knapp, Hopper \& Bell 1984; Herbert \& Straight 1989; Ylänne-McEwen 1993; Holmes 1995; Yuan 2002; Rees-Miller 2011; Lin, Woodfield \& Ren 2012), joiden aineisto on kerätty pääosin koeasetelmin, kyselytutkimuksin tai kirjaamalla havaitut kehut muistiinpanolapuille. ${ }^{3}$ Suomalaisistakin kehuista on tehty tutkimus, jossa koehenkilöitä pyydettiin esittämään kehuja roolileikkiasetelmissa (Ylänne-McEwen 1993). Keskustelunanalyysi tuo mukanaan aidon vuorovaikutustilanteen. Tutkittavana ei ole, miten ihmiset luulevat kehuvansa, vaan miten todellisuudessa kehutaan.

Kehuminen on toimintana sukua kannanottamiselle (Pomerantz 1978), ja kehut voidaankin lukea eräänlaisiksi erityislaatuisiksi kannanotoiksi: ne ovat vastaanottajaan kohdistuvia myönteisiä arvioita. Kehujen vastaanottaminen eroaa kuitenkin kannanottojen vastaanottamisesta siinä, että kehut tyypillisesti joko hyväksytään tai torjutaan. Kehujen kannanottoluonteen takia niitä voidaan kuitenkin käsitellä keskustelussa samoin kuin kannanottoja eli niihin voidaan reagoida saman- tai erimielisyyden ilmauksella. (Pomerantz 1978; myös Gathman, Maynard \& Schaeffer 2008.) Lisäksi kehut voivat kannanottojen tavoin olla osana muita toimintoja: esimerkiksi kiittämiseen sisältyy aina vastaanottajaa myönteisesti arvioiva aspekti, ja toisaalta kehut voivat sisältyä vaikkapa pyyntösekvensseihin. Tutkimuksen edetessä mietittäväksemme nousi, ovatko kaikki vastaanottajaan kohdistuvat positiiviset arviot kehuja (ks. myös Shaw \& Kitzinger 2012: 216-218). Ymmärryksemme mukaan kuitenkin se, että keskustelun vuorot ovat monitulkintaisia ja toimivat monella tasolla samanaikaisesti, on aivan olennainen inhimillisen vuorovaikutuksen piirre (ks. myös Levinson 2013): viime kädessä toimintojen tulkinnat vahvistuvat vasta siinä, millaisena vastaanottaja käsittelee niitä. Siksi sisällytimme aineistoomme kaikki vuorot, joihin sisältyy vastaanottajaa myönteisesti arvioiva potentiaali.

Pääaineistomme koostuu nauhoitetuista spontaaneista keskusteluista. Keskustelut ovat enimmäkseen peräisin Helsingin yliopiston suomen kielen oppiaineen keskusteluaineistoarkistosta. Lisäksi olemme käyttäneet tutkijoiden omia aineistoja. ${ }^{4}$ Olemme rajanneet aineistoksi ystävien ja perheenjäsenten väliset arkikeskustelut ${ }^{5}$. Korpuksemme

3. Golato (2005) esittelee laajasti aiempaa kehututkimusta ja tutkimusten metodologiaa kirjansa luvussa 2. Golaton esitys on erinomainen, emmekä ryhdy tässä toistamaan hänen ajatuksiaan. Oleellisin on se havainto, että kehuja on kyllä tutkittu runsaasti, useimmiten kohteliaisuustutkimuksen näkökulmasta, mutta aidoista nauhoitetuista keskustelutilanteista on tutkittu varsin vähän sitä, mitä kehuilla tehdään arkivuorovaikutuksessa.

4. Viittaamme Helsingin yliopiston suomen kielen oppiaineen keskusteluarkiston aineistoon merkinnällä SKL ja signum-numerolla (SKL; sg X) tai merkinnällä S (erityisen luvan vaativa aineisto). Olemme saaneet käyttöömme myös joitakin tutkijoiden omia aineistoja: Hanna Lappalaiselta saamamme aineisto on osoitettu Lappalainen-merkinnällä. Muissa tällaisissa aineistoissa ei ole lähdemerkintää.

5. Aineiston keskustelijat ovat eri-ikäisiä naisia ja miehiä eri puolilta Suomea. Aineisto on kuitenkin painottunut naisten keskusteluihin. Siksi suurin osa aineistomme kehuista on naisen naiselle esittämiä. Joissakin aiemmissa tutkimuksessa on esitetty, että naiset esittäisivät kehuja miehiä enemmän (ks. esim. Holmes 1995: luku 4). Aineistomme avulla tätä väitettä ei kuitenkaan voi todentaa, koska siinä on suhteellisen vähän miesten tai naisten ja miesten välisiä keskusteluja. 
koostuu noin 48 tunnista keskusteluja. Tästä aineistosta löysimme 51 kehujaksoa; yhdessä jaksossa voi olla useita kehuvuoroja ja -lausumia, joissa kehun kohde pysyy samana. Näin on seuraavassa esimerkissä, jossa Ella kehuu samassa jaksossa kahdesti (r. 3-4 ja 20-21) Arjan lukemista seurakunnan tilaisuudessa.

(1) Kahvinkaatoon [SKL; sg 142 2a11]

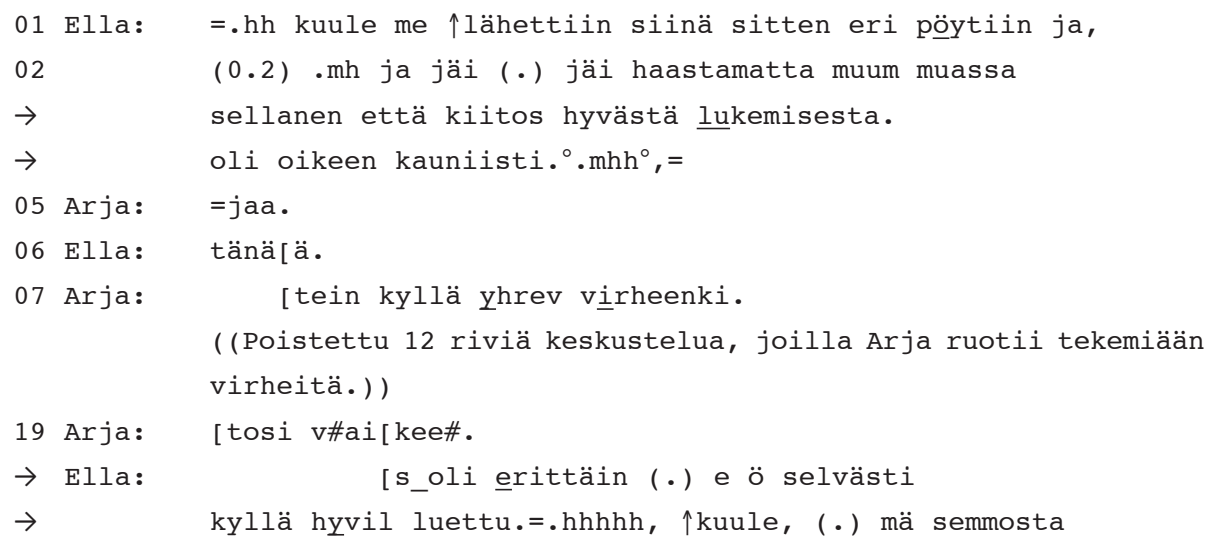

Yhdessä jaksossa voi olla useita kehuja myös siksi, että monenkeskisen keskustelun osanottajat kehuvat samaa asiaa. Esimerkissä 2 Liisan leipomaa kakkua kehuessaan Raija, Tinska ja Tyyne kehuvat samalla Liisan kakunleipomistaitoa.

(2) Taatelikakku [SKL; S-aineisto]

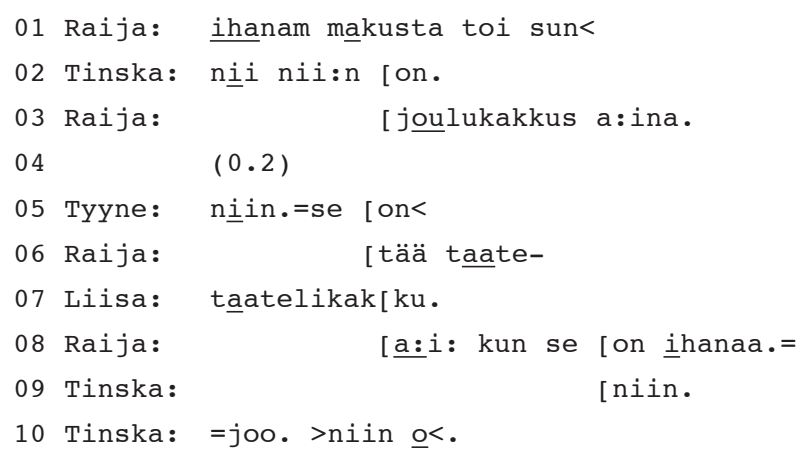

Tutkimuksen aineistoksi 51 kehujaksoa on pieni, joten tuntui tarpeelliselta hankkia suhteellisen nopeasti kerättävää tukiaineistoa. Helsingin yliopiston suomen kielen opiskelijat saivat keskustelunanalyysin peruskurssilla tehtäväksi tehdä muutaman päivän ajan huomioita kehujen käytöstä ja kirjoittaa mahdollisimman tarkasti muistiin kuulemansa kehujaksot. Opiskelijat kirjasivat kehuja näin: 
(3) Paita [muistiinpano; Puhujat A ja B ovat ystäviä, n. 20-vuotiaita naisia; keskustelu käydään tupakalla yliopiston edessä, menossa luennolle. Kehun kohteena B:n paita, josta ei ole puhuttu aiemmin.]

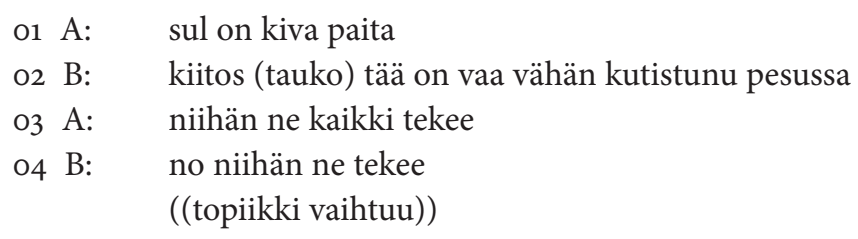

Muistiin on merkitty keskustelun tyyppi (puhelin- tai kasvokkaiskeskustelu), tilanne, osallistujat ja keskustelun kulku mahdollisimman tarkasti. Vaikka aineisto on osin epäluotettavaa niin puheen rakennepiirteiden kuin prosodian osalta, se on tukiaineistona käyttökelpoinen 65 tapauksen lisä. Se on esimerkiksi tuonut esiin tilanteita, jollaisia nauhoitetusta aineistosta ei löydy (esim. tapaamisia kadulla, kahvilassa tai kuntosalilla).

Olemme ryhmitelleet taulukkoon 1 aineistomme aineistotyypin (nauhoitettu keskustelu /muistiinpano) ja kehun fokuksen mukaan esitelläksemme, millaisia asioita aineistomme keskusteluissa kehutaan. Päluokittelu (puhujan persoona, ulkonäkö, omistamat asiat, teot ja taidot) on löyhä: esimerkiksi Suoritus ja taito -luokassa on monenlaisia kehuja, ja monien muidenkin luokkien tapauksia voisi sijoittaa myös siihen. Vaikkapa vaatteen kehuminen kohdistuu aina lopulta vaatteen valinneeseen henkilöön, hänen makuunsa ja pukeutumistaitoonsa. Suoritus-kehut on jaoteltu vielä sen mukaan, onko kehuttavana aikuinen vai lapsi. Näin siksi, että vaikka kaikki kehut ovat monifunktioisia, lasten kehumisella on myös kasvatuksellinen tehtävä, joka aikuisten kehuista puuttuu.

Taulukko 1.

Kehusekvenssien lukumäärä aineistotyypin ja kehun kohteen mukaan luokiteltuna $(\mathrm{N})$.

\begin{tabular}{l|c|c|c} 
& Keskustelu & Muistiinpanot & Yhteensä \\
\hline Persoona ja luonne & $\mathbf{8}$ & $\mathbf{1}$ & $\mathbf{9}$ \\
\hline Ulkonäkö & $\mathbf{5}$ & $\mathbf{2 8}$ & $\mathbf{3 3}$ \\
\hline vaate & 2 & 17 & 19 \\
hiukset & 1 & 4 & 5 \\
muut & 2 & 7 & 9 \\
\hline Omistus & $\mathbf{1 0}$ & $\mathbf{8}$ & $\mathbf{1 8}$ \\
\hline asunto & 3 & 6 & 9 \\
esine & 7 & 2 & 9 \\
\hline Suoritus ja taito & $\mathbf{2 8}$ & $\mathbf{2 8}$ & 56 \\
\hline$\quad$ ruoka & 7 & 4 & 11 \\
aikuiset & 18 & 13 & 31 \\
\hline Yapset & 3 & 11 & 14 \\
\hline Yhteensä & 51 & 65 & 116 \\
\hline
\end{tabular}


Etenemme artikkelissa kehujen rakenteesta niiden vastaanoton kautta kehujen paikkaan ja tehtävään keskustelussa, ja eri aineistot saavat hieman erilaisen aseman artikkelimme eri luvuissa. Luvussa 2 esiteltävä rakenteen analyysi perustuu ainoastaan nauhoitettuun keskusteluaineistoon, koska muistiinpanot ovat tähän tarkoitukseen liian epätarkkoja. Sen sijaan luvussa 3, joka käsittelee kehujen vastaanottamista, on käytetty myös muistiinpanoaineistoa: vastaanoton yksi tehtävä on kehun hyväksyminen tai torjuminen, mikä on saatu tallennettua melko luotettavasti. Lisäksi vastaanottoon liittyviä selityksiä voidaan tarkastella myös vain sisällön kannalta. Myös kehujen paikasta ja tehtävästä (luku 4) muistiinpanotkin antavat usein tarpeeksi luotettavaa tietoa.

\section{Kehujen rakenne}

Tässä luvussa tarkastelemme kehuvuoron ja -lausuman rakennetta sekä pohdimme, miten lausuman rakenne palvelee kehumisen funktiota. Teemme ensin lyhyen yleiskatsauksen kehulausumien ja kehuvien vuorojen rakenteisiin, ja tarkastelemme sitten persoonamuotojen käyttöä; käsittelemme erityisesti ensimmäisen ja toisen persoonan käyttöä.

\subsection{Kehuvan lausuman ja vuoron rakenne}

Kehuvat lausumat eli lausumat, joilla kehutaan, ovat usein rakenteeltaan yksinkertaisia. Vähimmillään kyse voi olla pelkästä partikkelista tai partikkeliketjusta (esim. <voi että $>$ ) tai pelkästä luonnehtivasta sanasta (ihana). Nauhoitetussa aineistossamme oli kaikkiaan yhteensä 107 yksittäistä kehulausumaa. Taulukkoon 2 olemme eritelleet lausumat tyypeittäin rakenteen mukaan.

Taulukko 2.

Kehulausumat rakennetyypeittäin (N).

\begin{tabular}{|c|c|c|}
\hline Lausumatyyppi & Esimerkki & Yhteensä \\
\hline Kopulalause & & 48 \\
\hline yksinkertainen & tää on hyvää & 44 \\
\hline kompleksinen & on tosi hauska saada & 4 \\
\hline Yksipersoonaisen passiivin perfekti & sepä oli hyvin ajettu & 4 \\
\hline Verbitön luonnehdinta & iha:na, hyvää piirakkaa & 20 \\
\hline Omistuslause & $\begin{array}{l}\text { sulla on tommonen valosa } \\
\text { luonne }\end{array}$ & 6 \\
\hline Pelkkä partikkeli /partikkeliketju & voi että & 2 \\
\hline Muut & & 27 \\
\hline Yhteensä & & 107 \\
\hline
\end{tabular}


Taulukkoa 2 voi pitää suuntaa antavana, vaikka aineistomme ei olekaan riittävä kehuvien lausumien rakenteiden perusteelliseen tarkasteluun. Siitä käy ilmi, että yli puolet aineistomme kehuista ilmaistaan yksinkertaisilla, luonnehtivilla rakenteilla: kopulalauseilla ja verbittömillä ilmauksilla (myös Ylänne-McEwen 1993: 502-504). Suuri osa kehuvista lausumista on siis rakenteeltaan melko kaavamaisia ja yksinkertaisia. Näin on muissakin kuin suomenkielisissä keskusteluissa. Golaton (2005: 73-83) mukaan muun muassa saksalaiset kehuvat useimmiten yksinkertaisilla luonnehtivilla lausumilla. Samoin Holmes ja Brown (1987) sekä Manes ja Wolfson (1981) esittävät, että englannissa suurin osa kehuista tehdään kaavamaisin ja yksinkertaisin lausumin (ks. Golato 2005: 77).

Keskeinen syntaktinen muotti kehujen esittämiseen on aineistossamme yksinkertainen kopulalause (tää on hyvää), jossa subjekti-NP (tää) viittaa kehun kohteeseen ja predikatiivi-NP (hyvää) ilmaisee luonnehdinnan. Kopulalauseiden taajuus selittynee sillä, että niitä käytetään erityisesti luonnehtimiseen (ks. Tainio 1993: 19-23). Toinen syy vaikuttaisi olevan se, että ne ovat aineistomme perusteella monikäyttöisimpiä. Niitä käytetään myös esimerkiksi kehuttaessa asioita, jotka eivät ole osallistujien huomion kohteena juuri kehun edellä, mitä verbittömillä ilmauksilla ei voi tehdä. Lisäksi niitä voidaan käyttää kehuttaessa asioita, vaatteita, ulkonäköä, ruokaa ja jopa suorituksia, kuten seuraavassa puhelinkeskustelussa (esim. 4). Virpi on kampaaja, ja hänen ja hänen siskonsa Millan mummu on ollut Virpin asiakkaana. Kehuessaan mummun tukkaa Milla kehuu samalla Virpin taitoja hiusten leikkauksessa:

(4) Mummun tukka [Lappalainen]

01 Milla: joo(h). (.) mut mummun tụkka oli hyvä?

02 Virpi: $\uparrow$ no oliko.

Olemme laskeneet erikseen sellaiset kompleksiset kopulalauseet, joissa kokijana on nollapersoona ja subjektina A-infinitiivi (esim. on tosi hauska saada kukkia). Esiintymiä on vain muutama, mutta ne ovat huomionarvoisia, koska ne kaikki kohdistuvat johonkin vastaanottajan tekoon ja niillä ilmaistaan teon kehun antajassa aikaansaamaa tunnetta. Niissä ei kuitenkaan ole viittausta kehun antajaan tai vastaanottajaan, ja siinä mielessä ne ovat samankaltaisia kuin useimmat muut kehulausumat: sen sijaan, että kehu esitettäisiin muodossa minusta on tosi hauska saada, se esitetään muodossa $\emptyset$ on tosi hauska saada.

Oma rakennetyyppinsä ovat niin kutsutut yksipersoonaisen passiivin perfektit ( $k y l$ se sit ol valtava hyvi ajettu, ks. esim. 5), jotka muistuttavat osittain kopulalauseita. Niilläkin voidaan luonnehtia vastaanottajan suoritusta ilman, että häneen itseensä viitataan. Näissä kehuissa pääpaino on suorituksen lopputuloksessa (ks. Helasvuo 2006).

(5) Hyvin ajettu [Turun puhekielen aineisto (SKL; sg oo8)]

01 Jape: mut kui kaua se matka kesti ${ }^{\circ} a\left[j a a ~\right.$ sit $^{\circ}$

02 Leea: [.hhh 
04 Leea: en mä muista.h >o'ink' mahtan' tunnin verran ajaa

Suorituksen lopputulos korostuu erityisesti, jos lausuman teemapaikassa on tilanneviitteinen pronomini, jonka tarkoitteeksi hahmottuu kehun vastaanottajan itsensä edellä raportoima suoritus. Niin on esimerkissä 5: siinä teemapaikassa oleva pronomini se (r. 6) viittaa pyöräilemiseen, josta Leea on edellä kertonut. Luonnehdinnan kohteena ei siis ole kehun vastaanottaja (Leea) vaan tämän suoritus (vrt. kyl sä sit ajoit valtavan hyvin). Yhdessä aineistomme esimerkkitapauksessa puhuja viittaa saamaansa kukkakimppuun lausumalla tää on kyl ajateltu. Tällöinkin kehuminen kohdistuu paitsi kukkakimppuun myös erityisesti kimpun valintaan tekona.

Kiinnostavaa on, että ainoastaan kahdesti aineistossamme vastaanottajan suoritusta kehutaan aktiivimuotoisen verbin sisältävällä lausumalla siten, että subjektina on toisen persoonan pronomini (kyllä te vaan niin kauniisti olette hoitaneet). Muissa tapauksissa suoritusta kehutaan esimerkiksi kopulalauseella, jossa on subjektina suorituksen kohteeseen tai tulokseen viittaava NP (mummun tukka), tai siten, että verbi on yksipersoonaisen passiivin perfektissä (on hyvin ajettu). Yksikön ensimmäisen ja toisen persoonan viittaukset näkyvätkin motivoituvan aina kontekstistaan käsin, ja siksi käsittelemme niitä erikseen (ks. alalukuja 2.2 ja 2.3).

Toisen suuren ryhmän muodostavat kehut, jotka muodostuvat pelkästä adjektiivista (ihana), adjektiivista ja substantiivista (hyvää piirakkaa) tai jopa pelkistä partikkeleista (voi että). Kun kehu koostuu pelkistä partikkeleista, luonnehdinta ilmaistaan prosodisin keinoin esimerkiksi painotuksilla ja äänteiden venytyksillä. Verbittömillä lausumilla ilmaistut kehut kohdistuvat aineistossamme asioihin, jotka ovat meneillään olevassa tilanteessa keskustelijoiden yhteisen huomion kohteena (myös Golato 2005: 66-67). Sellaisia ovat esimerkiksi ruoka, jota keskustelijat parhaillaan syövät, tai asiat, jotka ovat tilanteessa esillä ja joista on juuri puhuttu.

Kopulalauseiden lisäksi monikäyttöisiä ovat omistuslauseet, joissa on omistajaan viittaava NP, olla-verbi, luonnehtiva ilmaus ja kehun kohteen ilmaiseva NP (sulla on hyvännäköset housut). Aineistomme mukaan niitä käytetään, kun kehutaan vastaanottajan luonnetta (sulla on tommonen valosa luonne), vaatetusta tai omaisuutta (sulla on hyvännäköset housut tai kyl teill on Julle kauhean kiva se teiän kesäpaikka on). Nauhoitetussa aineistossa on vain muutama vaatetukseen tai ulkonäköön kohdistuva kehu. Oletettavasti niitä kuitenkin esitetään enemmän kuin aineistomme antaa ymmärtää, koska tukiaineistomme mukaan niitä esitetään spontaanisti esimerkiksi kadulla tai ravintolan naistenhuoneessa. Omistuslauseiden ja verbittömien lausumien (ihana paita) osuus saattaa siis todellisuudessa olla suurempi kuin taulukkomme näyttää.

Taulukon 2 kohta Muut sisältää muodoltaan suuresti varioivia lausumia. Muiden lausetyyppien runsaan lukumäärän ja variaation voi katsoa osoittavan, että kehuja esitetään usein muun toiminnan lomassa ja että niitä käytetään usein tukemaan muuta toimintaa. Tällöin kehuvuoron rakenne on sovitettu siihen toimintaan, jota kehu kul- 
loinkin tekee: muotoilu heijastaa sitä, mikä toiminta kehuvuorossa on etualaisena. Käytännössä lähes mitä tahansa rakennetta voi oletettavasti käyttää kehumiseen, kunhan konteksti on oikea. (Kehulausumien rakenteellisesta variaatiosta ks. Shaw \& Kitzinger 2012.) Esimerkissä 6 kehuva adjektiivi vahvaa sisältyy transitiivilauseen muotoiseen pyyntöön (ks. tarkemmin esimerkkiä 22):

(6) Trio [SKL; Sg 6 1a1]

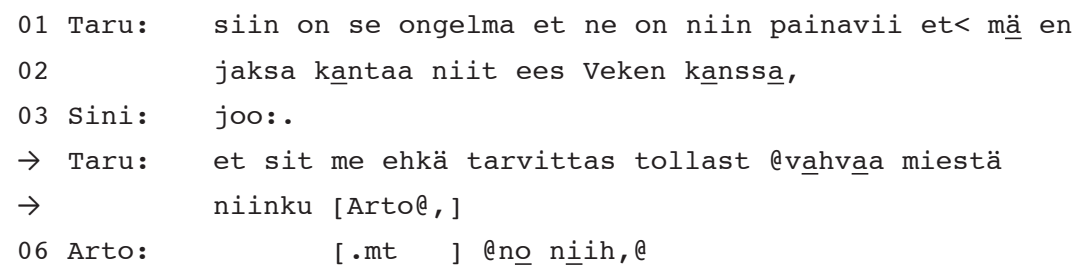

Vaikka kehuvien lausumien rakenne vaihteleekin suuresti, on suurin osa rakenteeltaan melko yksinkertaisia ja kaavamaisiakin. Myös puheenvuorot, joissa kehu esitetään, ovat kokonaisuudessaan rakenteeltaan melko yksinkertaisia. Suurin osa aineistomme kehuvuoroista koostuu yhdestä tai kahdesta vuoron rakenneyksiköstä:

(7) Kesäkeiton makuinen piirakka [Lappalainen]

Teea: hyvää piirakkaa

(8) Lasit [SKL; sg 151]

Kati: .hhh nuo on kivat nuo Annin lasi;t,

(9) Syntymäpäivät [SKL, S-aineisto]

Laila: nịi: ja kyl te olitte reippaita.

Kahdesta yksiköstä koostuva vuoro sisältää useimmiten vastaussanan (esim. nịi::) ja kehuvan lausuman (esim. ja kyl te olitte reippaita), kuten esimerkissä 9. Rakenteeltaan yksinkertaiset kehuvuorot aloittavat usein puhejakson, jonka aikana keskustelijoiden huomio on kehun kohteessa. Aineistossamme on kuitenkin myös kehuvuoroja, jotka koostuvat useasta vuoron rakenneyksiköstä ja ovat siten rakenteeltaan monimutkaisia. Niitä käytetään silloin, kun kehuminen palvelee jotain toista toimintaa, esimerkiksi kiittämistä tai pyytämistä. Esimerkissä 10 kehut (r. 3-4 ja 20-21) palvelevat kumpaakin.

(10) Hyvä lukeminen [SKL; sg 142 2b3]

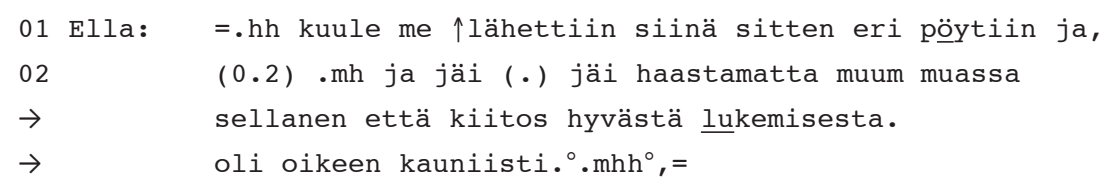




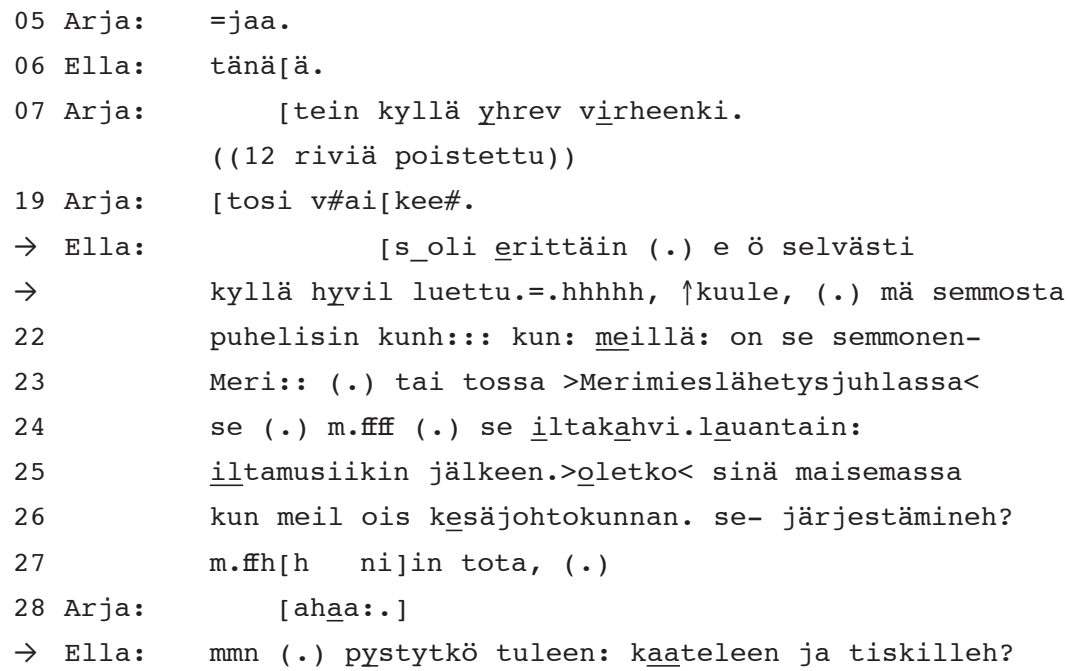

Ella on soittanut Arjalle pyytääkseen tätä avuksi seurakunnan kesäjuhlien kahvitarjoilussa. Ennen pyynnön (r. 29) esittämistä hän kuitenkin kiittää Arjaa lukemisesta ja kehuu samalla lukemista hyväksi. Vuoro riveillä 1-4 koostuu kolmesta rakenneyksiköstä: huomionkohdistimella kuule alkavasta selityksestä, kiittävästä lausumasta ja kehuvasta lausumasta. Vuoronalkuinen partikkeli kuule ja kiittävän lausuman sisältämä ilmaus muum muassa (r. 2) vihjaavat, että Ellalla on kiitoksen lisäksi muutakin asiaa (ks. myöhemmin esimerkkiä 23).

Vuoroa seuraa jakso, jonka aikana Arja kertoo tehneensä virheen ja sanoo tekstin olleen vaikea. Ellan seuraava vuoro (r. 20-27, 29) on jälleen moniyksikköinen. Sen aikana Ella saattaa ensin kehuvan jakson loppuun uudella kehulla (r. 20-21), jota voi pitää myös reaktiona Arjan edellä esittämään itsekritiikkiin, ja siirtyy sitten pohjustamaan pyyntöä (r. 20-27) sekä esittämään sen (r. 29). Kaiken kaikkiaan Ella tekee rivien 1-4 ja 20-27, 29 vuoroilla monta toisiinsa kytkeytyvää asiaa, hän muun muassa kiittää, kehuu, lohduttaa, pohjustaa ja pyytää. Toisin sanoen vuorot ovat toiminnallisesti monimutkaisia, mikä heijastuu vuorojen rakenteen monimutkaisuutena.

Kehuvan lausuman ja vuoron rakenne on siis aineistomme perusteella melko yksinkertainen silloin, kun kehuminen on vuorossa etualaisena toimintana. Rakenteen yksinkertaisuus ei sinänsä ole yllättävä havainto. Kehu on myös kannanotto, ja vähimmillään kannanoton ilmaiseminen edellyttää jonkinlaista luonnehtivaa ilmausta. Lisäksi kannanotto voi sisältää luonnehdinnan kohteen ilmaisevan tai siihen viittaavan NP:n (ihanaa kakkua, tää on ihana) sekä viittaavan NP:n ja luonnehdinnan yhdistävän kopulan (olla). Keskusteluvuorot ovat kuitenkin monitulkintaisia ja toimittavat samanaikaisesti useampia tehtäviä. Kielellinen toiminta toteutetaan kielellisin rakentein: kehuissakin rakenteen monimutkaisuus näyttää ilmentävän toiminnan kerroksisuutta.

Suomalaisten kehulausumien rakenteen yksinkertaisuutta lisäävä piirre on se, että lausumat ovat usein persoonattomia: niissä ei ole viittauksia kehujaan eikä kehun kohteeseen. Ensimmäisen tai toisen persoonan viittauksia sisältävät kehulausumat ovat siis 
harvinaisia, mikä kutsuu miettimään, milloin persoona sitten laitetaan kehussa esille. Seuraavaksi käsittelemmekin sitä, mikä motivoi persoonien käytön kehuissa.

\subsection{Ensimmäisen persoonan käyttö kehuissa}

Suurin osa aineistomme kehuista esitetään vailla ensimmäisen persoonan viittausta eli viittausta kehujaan itseensä: kehuja ei siis merkitse kannanottoa pelkästään omaksi mielipiteekseen vaan esittää sen ikään kuin yleisenä tosiasiana (vrt. amerikanenglanti, ks. alalukua 3.2). Yksikön ensimmäisen persoonan käyttö näyttää liittyvän tietynlaisiin konteksteihin ja toimintoihin. Aineistossamme on vain kolme lausumaa, joissa puhuja ilmaisee kehun nimenomaan omaksi mielipiteekseen. Ne kaikki motivoituvat juuri meneillään olevasta toiminnasta. Yksi tällainen kehu (esim. 11) esitetään kohdassa, jossa kehun vastaanottaja (Anni) itse on juuri arvioinut kehun kohdetta eli tässä tapauksessa vanhoja silmälasejaan kielteisesti. John Lennoneilla (r. 3) Anni viittaa entisiin silmälaseihinsa.

(11) Lasit [SKL; sg 151]

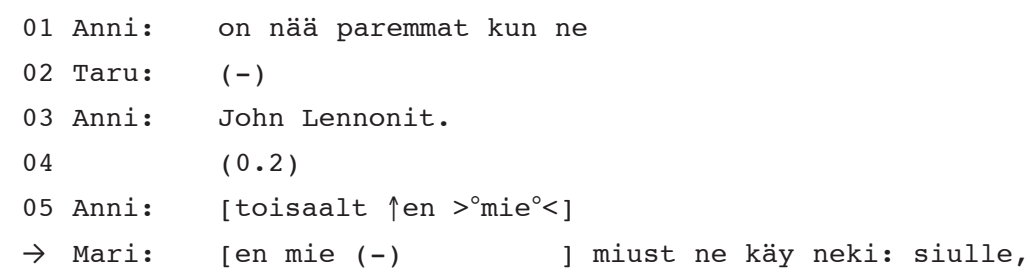

Kehun vastaanottaja on juuri edellä ollut eri mieltä kehun aiheesta eli vanhoista silmälaseistaan. Merkitsemällä kehun mielipiteekseen (miust, r. 6) puhuja säilyttää kantansa ja välttää siten arvioimasta vastaanottajan vanhoja laseja kielteisesti. Samalla hän jättää tilan vastaanottajan mielipiteelle (vrt. Rauniomaa 2007: 228-233). Ensimmäisen persoonan käyttöä voi siis pitää ratkaisuna ristiriidalle, joka syntyy siitä, että keskustelussa on preferoitua toisaalta olla samanmielinen keskustelukumppanin kanssa, toisaalta olla arvioimatta tätä kielteisesti (ristiriitaisista preferensseistä ks. Schegloff 2007: 76-78).

Kahdessa muussa tapauksessa meneillään on jakso, jonka aikana keskustelijat puhuvat keskinäisistä suhteistaan. Näytämme niistä toisen (esim. 12). Siinä äiti (Arja) ja tytär (Virpi) keskustelevat äitisuhteistaan.

(12) Äiti [Lappalainen]

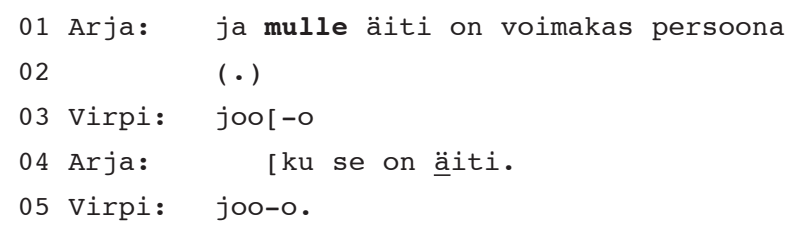




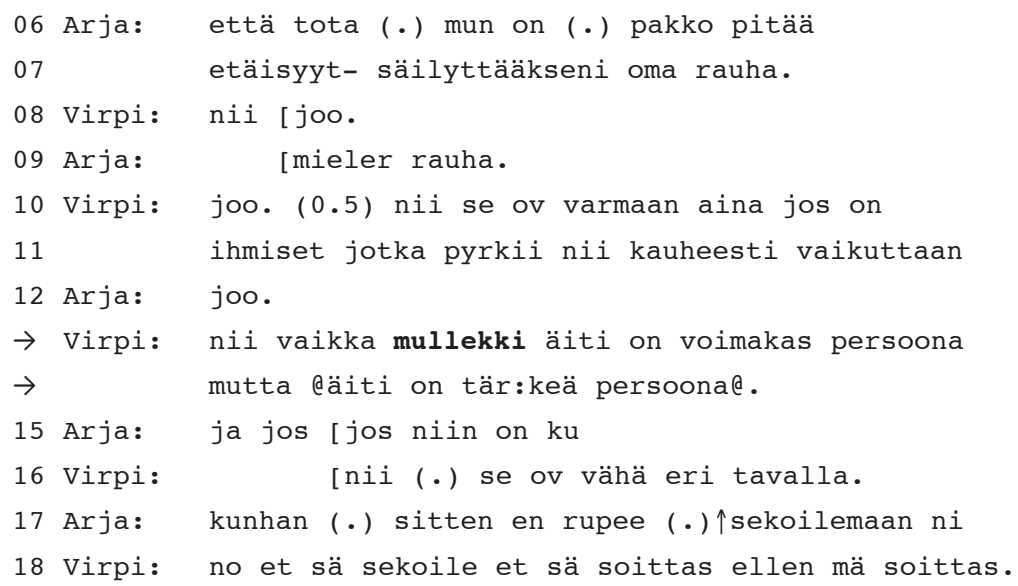

Katkelmassa on meneillään huoltenkerrontaa muistuttava jakso, jonka aikana Virpin äiti Arja kertoo omasta äitisuhteestaan (r. 1-9). Suhde perustellaan hankalaksi sillä, että Arjan äiti on voimakas persoona (r. 1). Rivillä 13 Virpi ottaa vuoron, jossa toteaa, että hänellekin äiti on voimakas persoona, mutta jatkaa heti perään äidin olevan myös tärkeä. Vuoroa jatkavassa lausumassa ei ole yksikön ensimmäisen persoonan viittausta, mutta siihen on tulkittavissa nolla-anafora (Ø äiti on tär:keä persoona). Se luonnehtii nimenomaan Virpin suhdetta äitiinsä, ei äitejä yleensä. Rivillä 16 Virpi vielä täsmentää oman käsityksensä. Katkelman alussa Arja on kertonut omasta äidistään ja suhtautumisestaan tähän; puhe Arjan äidistä on samalla puhetta Arjasta itsestään. Arja itse on Virpin äiti. Ottamalla esille keskustelijoiden välisen äiti-tytärsuhteen Virpi muuttaa puheenaiheeksi Arjan eli oman äitinsä (r. 13-14). Keskustelu jatkuukin siitä, minkälainen äiti Arja on. Tässä tapauksessa ensimmäisen persoonan käyttö motivoituu toisaalta siitä, että rivien 13-14 vuorossa Virpi kierrättää Arjan aiemmin käyttämää rakennetta mulle äiti on voimakas persoona (r. 1). Toisaalta ensimmäinen persoona motivoituu siitä, että keskustelijat puhuvat henkilökohtaisista kokemuksistaan ja äitisuhteistaan.

Esimerkki on kaikkiaan monimutkaisempi kuin tämä analyysi näyttää: meneillään on monta affektisesti latautunutta aihetta sekä lisäksi neuvottelu siitä, mistä niistä puhutaan ja millä tavoin. Puhe on ainakin Arjan suhteesta omaan äitiinsä, Virpin suhteesta Arjaan ja siitä, minkälainen tytär ja äiti Arja on. Kierrättämällä Arjan käyttämää rakennetta sekä käyttämällä sanaa äiti toisen persoonan pronominin sä sijasta Virpi muovaa tilannetta, jossa kaksi naista keskustelee äideistään, ja välttyy siirtämästä puhetta suoraan siihen, minkälainen äiti Arja on. Vuoro osoittaa ymmärrystä keskustelukumppanin kokemusta kohtaan; samalla se sanoutuu irti kielteisestä arviosta, mistä ovat merkkinä konsessiiviset konjunktiot vaikka ja mutta sekä myönteinen arvio tärkeä.

Esimerkkiemme perusteella vaikuttaa siltä, että ensimmäisen persoonan käyttö suomenkielisen keskustelun kehuissa liittyisi tilanteisiin, joissa tavalla tai toisella käsitellään keskustelijoiden välisiä suhteita. Kaikkiaan puheaktipersoonia eli ensimmäistä ja toista persoonaa näkyy vältettävän peruskehuissa: myös toisen persoonan käyttö vaikuttaa liittyvän erityisiin konteksteihin. Sitä käsittelemme seuraavaksi. 


\subsection{Toisen persoonan käyttö kehuissa}

Suuri osa kehuista esitetään nauhoitetussa aineistossamme vailla eksplisiittistä viittausta kehun vastaanottajaan. ${ }^{6}$ Aineistomme 51 kehujaksosta vain 14:ssä käytettiin toisen persoonan pronominia, yhdessä sukulaisuustermiä äiti, kolmessa erisnimeä ja yhdessä kolmannen persoonan pronominia viittaamaan kehun vastaanottajaan. Kaikki erisnimet esiintyivät monenkeskisissä keskusteluissa. Kerran erisnimeä käytettiin yhdessä toisen persoonan pronominin kanssa ja erisnimi toimi rakenteesta irrallisena puhutteluna (ks. Seppänen 1998: 95-96). Kaikissa erisnimitapauksissa kehuvalla vuorolla oli muitakin tehtäviä: sitä käytettiin pyytämiseen tai uuden puheenaiheen tarjoamiseen. Samalla vuoro kuitenkin toimi myös kehuna, jolloin erisnimen käytön voi katsoa nostavan kehun vastaanottajan muidenkin huomion kohteeksi, mikä korostaa lausuman kehuvuutta (mts. 105).

Erityisen kiinnostavaa aineistossamme on toisen persoonan käyttö. Se rajoittuu konteksteihin, joissa on juuri puhuttu vastaanottajasta ja erityisesti silloin, kun on puhe tämän huolista. Kymmenessä aineistomme 14 tapauksesta toisen persoonan pronominia käytettiin kontekstissa, jossa kehun vastaanottaja oli ollut juuri esillä; kahdeksassa tapauksessa edellä oli ollut vihjeitä jonkinlaisesta vastaanottajaan liittyvästä ongelmasta tai huolesta, ja neljä niistä asettui meneillään olevaan huoltenkerrontajaksoon (ks. Jefferson 1988), kuten seuraavassa.

(13) Kukkakimppu [SKL; sg 141-143 2a5]

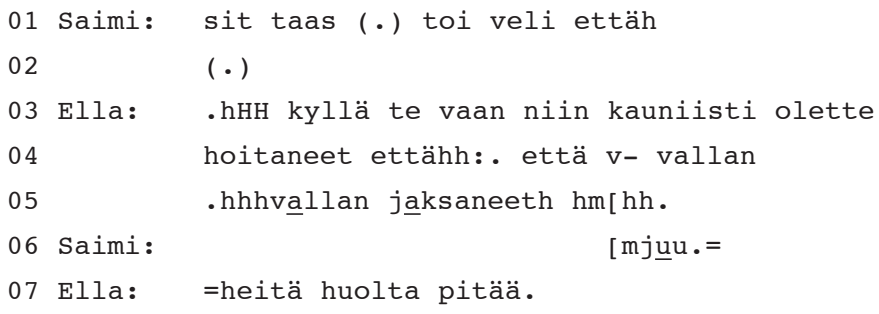

Ennen katkelmaa Saimi on pitkään kertonut veljestään, joka suree kuollutta vaimoaan, sekä siitä, miten hän käy miehensä kanssa hoitamassa niin veljeään kuin äitiäänkin. Huolen aiheena on ensisijaisesti ollut Saimin veli, mutta rinnalla kulkee myös huoli Saimin omasta jaksamisesta. Ellan vuoro (r. 3-5) poimii Saimin kerronnasta esiin juuri tämän: monikon toisen persoonan pronominilla te Ella viittaa Saimiin ja tämän mieheen.

Toisen persoonan käyttö kehuissa vaikuttaa siihen, mikä on vuoron fokuksessa: kehuttava asia vai kehun vastaanottaja - aina nämä eivät ole yksi ja sama asia. Se, mitä

6. On todennäköistä, että kehuja, joissa viitataan vastaanottajaan, esiintyy enemmän kuin nauhoitettu aineistomme näyttää. Nauhoitetusta aineistostamme puuttuvat lähes tyystin spontaanit, ulkonäköön tai vaatetukseen kohdistuvat kehut, joita esitetään usein omistuslauseilla (sul on kivat housut) hiukset). 
kehutaan, on huomionarvoista etenkin, kun puhutaan vastaanottajan suorituksesta. Suorituksia kehutaan useimmiten passiivissa tai kopulalauseella, jolloin kehu ei sisällä viittausta sen vastaanottajaan ( $k$ 'l se sit ol valtava hyvi a(h)jettu.h [esim. 5] ja mummun tukka oli hyvä. [esim. 4]), vaan huomion kohteena on suoritus. Oletettavasti tämä tekee kehun vastaanottamisen helpommaksi: vastaanottajan ei tarvitse puhua itsestään, kun hän voi puhua suorituksesta. Kun on kyse huoltenkerronnasta, on kuitenkin aina kyse myös huoltenkertojan henkilökohtaisesta kokemuksesta: huolenkertoja on mukana puheenaiheena, olipa huolen varsinainen aihe mikä tahansa. Huolen vastaanottajan tehtäväksi jää silloin tulkita, mitä edellisen puheen puolia hän nostaa reaktioissaan esille.

\section{Kehujen vastaanottaminen}

Yleinen uskomus on, että kehuminen on suomalaiselle kulttuurille vieras ilmiö ja että kehuun vastataan vähättelemällä, korkeintaan kiittämällä. Tällaisia uskomuksia löytyy muualtakin maailmasta, muun muassa saksalaisista käytösoppaista (Golato 2005: 167168). Suomessa esimerkiksi oppaassa Käytös- ja tapatieto (Seppälä \& Virkkunen 1977) kehujen on kerrottu olevan teennäisiä ja kehumiseen kehotettu vain, jos aihe nousee keskusteluun "helposti ja luonnollisesti". Kehusta kiittäminen ei kirjan mukaan kuulu suomalaiseen kulttuuriin. (Mts. 208, 209.) Keskusteluaineiston valossa uskomukset tai käytösoppaat eivät ole oikeassa: suomalaisessa keskustelussa kehumiset otetaan vastaan useimmiten myönteisesti ja kiittäminenkin kuuluu vastaanottajien repertuaariin (ks. myös Halonen 2010).

\subsection{Vastaanottamisen keinot ja vastaanottajan episteeminen asenne}

Tässä luvussa tarkastelemme kehujen vastaanottamista kahdenkeskisessä keskustelussa, joita aineistossamme on 74. Monenkeskisten keskustelujen monimutkaisempi dynamiikka jää tässä vaiheessa tarkastelun ulkopuolelle.

Analyysi nostaa esille kaksi olennaista piirrettä. Ensinnäkin kehut otetaan pääosin vastaan myönteisesti: tarkasteltavina olevista 74 kehuvuorosta 56 hyväksytään. Näin on esimerkiksi seuraavassa esimerkissä, jossa Reija ja Kaarina katselevat Reijan perimää, Reijan sukulaisen valmistamaa ryijyä. Sekventiaalisesti naiset tuottavat kaksi myönteistä kannanottoa; kehuksi kannanoton tekee se, että vaikka kannanotto koskee ryijyä (jonka on tehnyt kolmas, ei-läsnäoleva henkilö), se koskee kuitenkin osallistujista nimenomaan ja vain toista, Reijaa, hänen sukuaan ja kotiaan.

(14) Ryijy [SKL; sg 067]

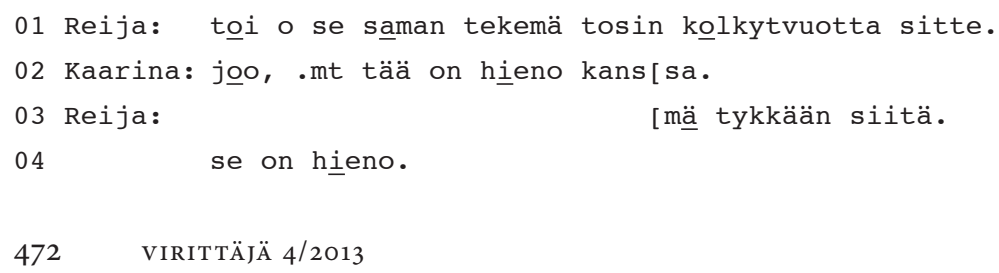


Reija vastaa Kaarinan kehuun tekemällä toisen myönteisen kannanoton (r. 3-4). Hän korostaa omaa näkökulmaansa vastaamalla itsenäisellä lauseella, jossa ei ole merkkiä siitä, että arvio olisi vastausasemassa (vrt. esim. nii onki; Heritage \& Raymond 2005; Raymond \& Heritage 2006). Seuraavassa esimerkissä hyväksyvä reaktio on sen sijaan muotoiltu vastaukseksi. Tyyne on kertonut Lailalle, kuinka hän huonosta säästä huolimatta lähti mökille ja kuinka ratkaisu osoittautuikin lopulta myös sään puolesta hyväksi (r. 1 ja 3). Tyynen kehuttua säätä Laila kehuu Tyynen ja tämän ystävän reippautta. Tässä Tyynen hyväksyvä vuoro (r. 6 joo) on laadittu selvästi vastaukseksi edeltävään arvioon.

(15a) Syntymäpäivät [SKL, S-aineisto]

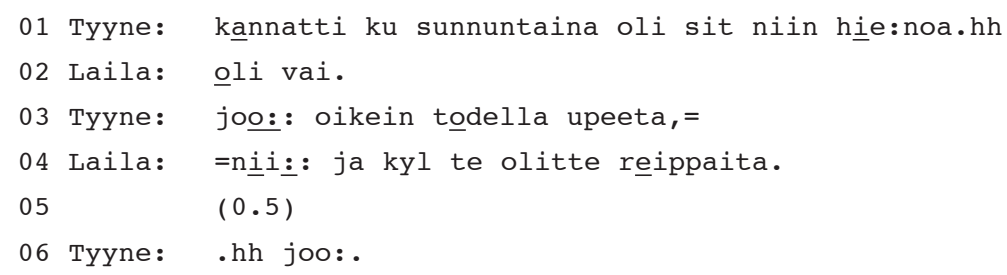

Esimerkeissä 14 ja 15a kehu siis hyväksytään, vaikkakin esimerkissä 15a pienellä viiveellä. Uskomusten vastaisesti empiirinen aineisto näyttää, että kehujen hyväksyminen on Suomessa tavallista. Tyypillistä kuitenkin on, että vaikka kehu hyväksytään ensin, sen jälkeen tarjotaan selitys. Vastaanottaja voi esimerkiksi tuoda ilmi, että ansio kehun kohteen erinomaisuudesta kuuluu itse asiassa jollekulle toiselle tai että kehun kohteessa on huonojakin puolia. Niin tekee Tyynekin, kuten esimerkin jatkosta (15b) näkyy. Hän selittää reippauttaan hyvällä säällä, jota hän kuvaa jopa viidellä myönteisellä adjektiivilla: loistava, tyyni, hiljainen, nätti ja ikimuistettava (r. 6, 8 ja 10).

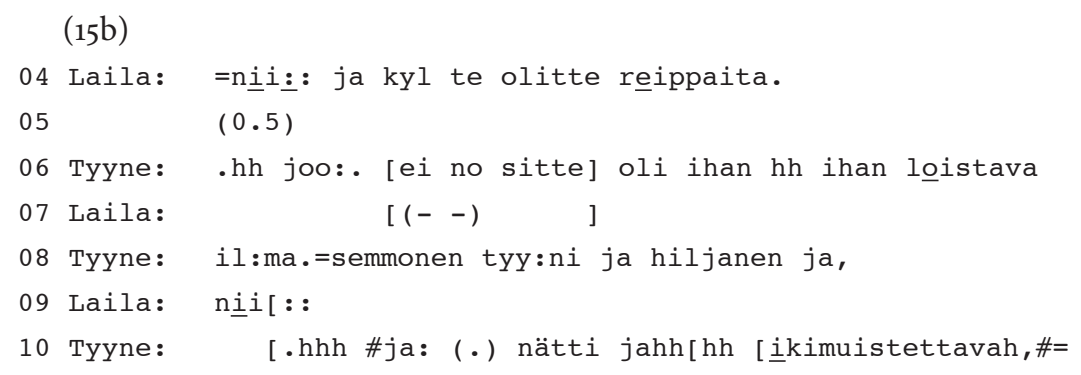

Kehut siis pääasiassa hyväksytään mutta niille tarjotaan selitys - tässä järjestyksessä.?

Toinen aineistosta esiin nouseva piirre on vastaanottajan osoittama tietämys arvioitavan kohteen luonteesta ja mahdollisesta kehuttavuudesta eli vastaanottajan epistee-

7. Näin ei tapahdu esimerkissä 14 , jossa kehutun ryijyn valmistaja ei ole paikalla. Aineistomme perusteella tämä on yksi kehujen vastaanoton tapaa erottava piirre. Kiitämme artikkelin nimetöntä arvioijaa tästä huomiosta. Aineisto on kuitenkin liian pieni siihen, että tällaista eroa voisi systemaattisesti tarkastella. 
minen asenne. Kyse on siitä, osoittaako vastaanottaja jollain tavalla, oliko hän itse jo miettinyt asiaa vai tuliko myönteinen arvio hänelle uutisena. Episteemisen asenteen eksplisiittinen ilmaiseminen liittyy sekä kehun aiheeseen että keskustelijoiden suhteeseen. Sen ilmaiseminen on yksi keino käydä keskusteluissa aina käynnissä olevaa neuvottelua siitä, kuka tietää mitäkin ja millainen suhde tietoon kenelläkin on - kuka tietää eniten tai on tiennyt ensimmäisenä. (Drew 1991; Heritage 2002; Heritage \& Raymond 2005; Raymond \& Heritage 2006; myös Stivers, Mondada \& Steensig toim. 2011.) Peräti 60 tapauksessa 74 :stä vastaanottaja tuo esiin oman tietonsa kehun kohteesta. Taulukko 3 osoittaa, miten vastaanoton tavat jakautuvat.

\section{Taulukko 3.}

Vastaanottojen jakauma. Vastaanotot on kursivoitu.

\begin{tabular}{|c|c|c|c|c|}
\hline & Kehu hyväksytään & Kehu torjutaan & $\begin{array}{l}\text { Ei eksplikoida kantaa / } \\
\text { käsitellään uutisena }\end{array}$ & Yht. \\
\hline $\begin{array}{l}\text { Episteeminen } \\
\text { asenne esillä }\end{array}$ & $\begin{array}{l}\text { sul on hyvän- } \\
\text { näköset housut - } \\
\text { eikö okki } \\
\quad 47\end{array}$ & $\begin{array}{l}\text { onpas sulla ki- } \\
\text { van pirtsakka } \\
\text { paita - no tää } \\
\text { nyt on tämmöne } \\
\quad 3\end{array}$ & $\begin{array}{l}\text { sulla on kyllä tosi } \\
\text { kivannäköset housut } \\
\text { - ai nää vai } \\
10\end{array}$ & 60 \\
\hline $\begin{array}{l}\text { Episteeminen } \\
\text { asenne ei esillä }\end{array}$ & $\begin{array}{l}\text { sul on kiva paita - } \\
\text { kiitos } \\
\qquad 9\end{array}$ & o & $\begin{array}{l}\text { kato ku ne ei oo nii } \\
\text { hauskoja ihmisii } \\
\text { [kuin sinä] - naurua } \\
5\end{array}$ & 14 \\
\hline Yhteensä & 56 & 3 & 15 & 74 \\
\hline
\end{tabular}

Taulukosta 3 näkee kaksi määrällisesti merkittävää kategoriaa: Ensinnäkin kehuista hyväksytään peräti $56^{8}$. Toiseksi hyväksytyistä vastaanotoista 47 tapauksessa episteeminen asenne on esillä. Teemmekin tässä vielä yhden rajauksen ja keskitymme seuraavaksi vastaanottojen suurimpaan ryhmään, episteemistä asennetta osoittaviin hyväksyviin vastauksiin.

\subsection{Kehujan kanssa samaa mieltä: kadonnut vaatimattomuus?}

Niin kutsuttu preferenssi- eli suosituimmuusjäsennys kertoo siitä, millaisen odotuksen jokin vuoro luo keskusteluun (ks. Pomerantz 1984; Heritage 1996 [1984]: 261-278; Tainio 1997; Schegloff 2007: 58-81). Preferenssijäsennys on samalla kertaa rakenteellinen ja sosiaalinen ilmiö: kielelliset valinnat osoittavat, käsitteleekö puhuja vuoroaan odotuksenmukaisena vai -vastaisena, ja kulttuurissa vallitsevat säännöt taas säätelevät sitä, millaisia odotuksia millainenkin toiminto kulttuurissa synnyttää. Pomerantz

8. Aineistonamme on monenlaisia keskusteluja, mutta varsinkin muistiinpanoaineistossa on paljon nuorten pääkaupunkiseudulla opiskelevien ystävysten keskusteluja, joita on kerätty opiskelutöinä. Tämä on syytä ottaa jossain määrin huomioon tuloksia arvioitaessa: tulos ei ole välttämättä totuus koko Suomesta ja kaikista ikäluokista. 
on tutkinut sekä preferenssijäsennystä yleisesti (1984) että erityisesti kehujen vastaanotoissa (1978). Hän osoittaa, että kehuihin reagoitaessa toimii kolme erilaista, osin päällekkäistä jäsennystä. Ensinnäkin kehu ennemmin hyväksytään kuin hylätään: siitä ennemmin kiitetään kuin väitetään vastaan. Toinen tavoite on samanmielisyys: vastaanottaja paitsi hyväksyy kehun toisen mielipiteenä myös yhtyy siihen. Kolmas erityisesti kehujen vastaanottamisessa olennainen tavoite - on itsekehun välttäminen. Pyrkimys samanmielisyyteen ja itsekehun välttämiseen ovat konfliktissa keskenään. Pomerantzin (1978) keskusteluaineistoon perustuva tutkimus osoittaakin, että amerikkalaisessa kulttuurissa vastaukset kehuihin ovat näiden kahden väliltä. Vastaanottajat usein hyväksyvät kehun pääasiassa kiittämällä ja esittämällä toisen, mutta lievemmän myönteisen kannanoton tai selityksen ${ }^{9}$ (esim. oh it was just beautiful - well thank you uh I thought it was quite nice, mas. 108). He siis ratkaisevat hyväksymisen kiittämällä ja samanmielisyyden ja itsekehun välttämisen ristiriitaisen vaateen esittämällä omanaan kehua lievemmän myönteisen arvion. Itsekehun välttäminen näyttää olevan preferenssi amerikkalaisessa keskustelussa. Myös suomalaisen kehun vastaanoton rakenne näyttää samantyyppiseltä ${ }^{10}$ : kehut ensin hyväksytään, sitten niille tarjotaan selitys. Suuria eroja on kuitenkin hyväksymisen keinoissa ja samanmielisyyden asteessa. Ennen näihin keinoihin syventymistä teemme vielä katsauksen saksan- ja englanninkielisiin kehuihin ja niiden vastaanoton eroihin, koska erityisesti saksankieliset kehusekvenssit näkyvät etenevän usein rakenteita myöten samalla tavalla kuin suomenkieliset.

Saksalaisissa etikettikirjoissa esitetään (ks. Golato 2005: 167-168), etteivät saksalaiset yleensä hyväksy kehuja vaan torjuvat ne vähätellen. Golaton keskusteluaineistossa ihmiset kuitenkin yleensä hyväksyivät kehun ja osoittivat olevansa samaa mieltä tai jopa päätyneensä jo aiemmin samaan arvioon. Kysymys saattaa olla kulttuurieroista. Golato esittelee (mts. 195-196) Kotthoffin (1989: 451-452) tekemän, pieneen testiin perustuvan tutkimuksen amerikkalaisten ja saksalaisten suhteesta kehumiseen. Sen mukaan saksalaiset suuntautuvat enemmän kehun todenmukaisuuteen ja amerikkalaiset sen sosiaalisiin tehtäviin (ks. myös Byrnes 1986: 200-201). Kehujen rakenne saattaa heijastaa tätä eroa. Amerikkalaiset, englanninkieliset kehut rakennetaan suomalaisia ja saksalaisia useammin kehujan näkökulmaa korostaviksi rakenteella yksikön 1. persoona + verbi like tai love (esim. I loved your Christmas card; Pomerantz 1978: 108; Wolfson \& Manes 1980; Holmes \& Brown 1987). Arvio on siis verbissä, ja siten se hahmottuu verbin subjektin - edeltävässä esimerkissä minän - näkemykseksi. Saksankieliset kehut taas rakennetaan näennäisesti objektiivisiksi kopulalla, verbillä sein 'olla' (esim. Das is ja süß das milchdöschen 'tuo on niin sievä tuo kermakko', Golato mts. 81, myös 77-78, 87). Rakenne-ero korostaa sitä tulkintaa, että amerikkalaisen esittämä kehu olisi subjektiivisempi eikä sillä pyrittäisikään yleiseen todenmukaisuuteen, kun

9. Käytämme sanaa selitys kattoterminä kaikille niille lausumille ja vuoroille, joilla kehun vastaanottaja ensimmäisen vastauksensa jälkeen jotenkin muokkaa joko vastaustaan tai kehun kohdetta. Selitystermin alle mahtuu näin niin ostopaikan kuvaus ostin Hömppälinnan Piipmarketista kuin luonteen perusta se on ollu vähä Luoja lahjaa tai hyvistä housuista esitelty huono puoli tää kuminauha o aika löysä.

10. Pomerantzin tutkimustulosten suora soveltaminen tai vertaaminen suomalaiseen aineistoomme on hankalaa ja osin mahdotonta siksi, että hän käsittelee artikkelissaan niin kolmanteen osapuoleen kuin vastaanottajaan kohdistuvia kehuja eikä esimerkeistä käy useinkaan ilmi, millaisesta tilanteesta on kyse. 
saksalaiset taas pitäytyisivät "tosiasioissa". Golaton (2005: 193-196) mukaan erosta voi seurata, että saksalaiset hyväksyvät kehun amerikkalaisia useammin - koska kehu on muotoiltu yleiseksi tosiasiaksi mielipiteen sijaan. Luvussa 2 kävi ilmi, että myös suomalaiset kehut muotoillaan pääosin olla-verbillisillä rakenteilla. (Amerikan)englannin ja saksan kehujen vastaanottamisen eroa vahvistaa myös Huthin tutkimus (2006) saksaa opiskelevien, äidinkieleltään englanninkielisten saksaksi käymistä keskusteluista ja heidän kokemuksistaan niistä. Keskustelut eivät olleet "aitoja" siinä mielessä, että opiskelijoille oli annettu tehtäväksi keskustelun aikana kehua vastapuolta; kehun aihetta sen sijaan ei ollut määrätty. Alla on yksinkertaistettu versio yhdestä kehusta:

(16) Schönes jacke [Huth 2006: 2040]

$$
\begin{array}{ll}
\text { o1 A: } & \text { du hast ein schönes jacke } \\
\text { ['sinulla on nätti takki'] }
\end{array}
$$

Esimerkki osoittaa sen, miten opiskelija B suuntautuu siihen, että kehun kontekstina on nyt saksalainen kulttuuri. Kiitettyään kehusta hän tekee itsekorjauksen, jonka hän aloittaa englanninkielisellä partikkelilla (I mean). Keino korostaa itsekorjauksen metakielellistä tehtävää: opiskelija kommentoi sanomisiaan muuttamalla vastaanoton lajin yllättyneestä kiitoksesta itsestäänselvyyden kuittaukseksi. Myös nauru vastauksen lopussa näyttää, että opiskelija suuntautuu toimintaansa tietoisesti ja pitää sitä ongelmallisena (vrt. Haakana esim. 1999: 143-154). Tehtäväkeskustelujen jälkeen opiskelijoiden tuli reflektoida, millaisia tunteita saksaksi kehuminen heissä herätti. Kaikki pitivät ongelmallisena sitä, että saksaksi kehut otetaan vastaan niin auliisti; usein saksalainen tapa koettiin ylimieliseksi. (Huth 2006: 2047.)

Aineistomme perusteella suomalaisissa keskusteluissa kehut hyväksytään yhtä herkästi kuin saksalaisissa ja vastaus osoittaa usein, että vastaanottaja on jo itse ajatellut asiaa. Myös suomalaisessa kulttuurissa on vallinnut stereotyyppinen käsitys tai ideaali, että suomalainen "tarkoittaa mitä sanoo" (ks. esim. Seppälä \& Virkkunen 1977). Tätä oletettua ja kielen rakenteilla muotoiltua rehellisyyttä ihmiset usein vertaavat juuri käsitykseen amerikkalaisesta tavasta sanoa myönteisiä asioita (myös) vain kohteliaisuudesta. Käsitystä toden puhumisesta voi tukea se, että kehuja harvemmin viittaa itseensä, mikä nostaa esille nimenomaan arvion kohteen ja rakentaa arvion "objektiiviseksi" tosiasiaksi (ks. lukua 2). Suomalaisissa kehujen vastaanotoissa itsekehun välttäminen saa väistyä samanmielisyyden tieltä.

\subsection{Vastaanottovuoron jäsennys: samanmielisyys ja itsekehun välttäminen}

Kehun hyväksymiseen on monia kielellisiä keinoja. Vastaanottaja voi toistaa toisen antaman myönteisen arvion omanaan (ks. esim. 14), osoittaa kehun itsestäänselvyydeksi (Sä oot kaunis - No tietysti oon) tai käsitellä kehua odotettuna, kalastettuna (Kyllä muutosta on tapahtunu - Kiitos ton mä vaan halusin kuulla; ks. tarkemmin seuraa- 
vaa lukua). Näissä myös episteeminen asenne on pantu esille esimerkiksi adverbiaalilla tietysti tai eksplikoimalla kehun olevan kalasteltu. Tällaisissa vastaanotoissa on usein kyse leikittelystä. Yltiöpositiivinen vastaanotto luo ironiaa, jolla voidaan kommentoida koko toimintaa, sekä kehumista että vastaanottoa.

Tavallinen hyväksymisen keino on myös kielteinen vaihtoehtokysymys eiks o(o)kki, joka vastaa tehtävältään suurin piirtein englannin ja saksan liitekysymyksiä isn't it tai ne. Tällainen kysymys vastauksen paikalla osoittaa puhujan paitsi olevan samaa mieltä myös päätyneen tuohon arvioon itse jo aiemmin. (Golato 2005: 178-180; Harren 2001: 110-111.) Näin vastaanottaja tekee seuraavassa esimerkissä, jossa ystävä (B) kehuu A:n housuja. Ensin A hyväksyy kehun -kin-partikkelin sisältävällä kielteisellä vaihtoehtokysymyksellä (r. 3) ja tuo sen jälkeen esille myös housujen huonon puolen (r. 6-7).

(17) Hyvännäköiset housut [SKL, S-aineisto]

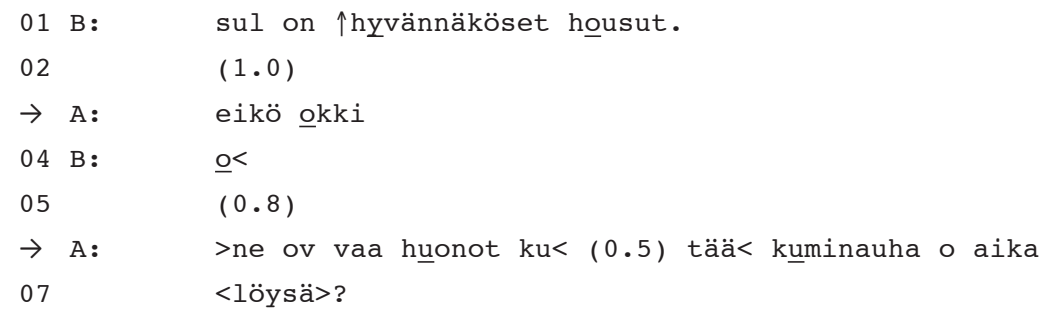

Kysymysmuotoinen lausuma osoittaa, että vastaanottaja on jo itse aiemmin päätynyt samaan arvioon. Toisaalta valitsemalla nimenomaan kysymysrakenteen vastaanottaja käsittelee kehujaa yhtä pätevänä arvioijana. Kysymyksellä vastaanottaja tavallaan irrottautuu vastaanottajan roolista ja asettuu kehujan rinnalle arvioijaksi. Esimerkkitapauksessa kehuja myös käsittelee vuoroa kysymyksenä vastaamalla siihen (r. 4). Lopulta kehun vastaanottaja tuokin sitten ilmi vian kehun kohteessa (housujen löysä kuminauha r. 6). Vastaanottaja siis orientoituu sekä samanmielisyyden että itsekehun välttämisen odotuksiin.

Tavallisin kehun hyväksymisen keino on vastaussana (dialogipartikkeli), etenkin jatkossa käsiteltävät joo (13/56) ja nii (9/56). Esimerkissä 18 Reija vastaa ryijyään koskevaan kehuun (r. 1) joo-partikkelilla (r. 2).

(18) Pöytäliina ja ryijy [SKL; sg o67]

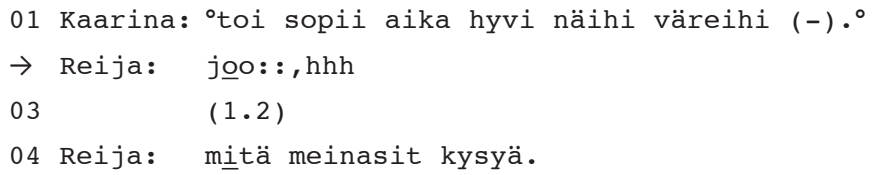

Sorjosen mukaan (2001: 199) joo käsittelee tällaisessa tilanteessa edellistä vuoroa ennemmin informaationa kuin arviona. Ohittamalla kehun arvioivan luonteen vastaanottaja voi samalla hyväksyä sen ja välttää itsekehun (mts. 154, 199, 203). Ke- 
hun käsitteleminen pelkkänä informaationa tekee kuitenkin myönteisestä arviosta itsestäänselvyyden. Siksi vastaanottaja samalla tulee osoittaneeksi, että hän on itse ajatellut asiasta samalla tavalla ja toisaalta ettei puhujalla ole asiasta enempää sanottavaa.

Myös seuraava muistiinpanoon perustuva esimerkki osoittaa, että joo-partikkelilla käsitellään myös kehun arvioluonnetta. Tässä partikkelia seuraa erittäin tyypillinen selitys: kehumisen kohteen ostopaikka.

\section{(19) Korvakorut [muistiinpano]}

o1 A: sullon muuten kivannäköset korvakorut,

$\rightarrow$ B: $\quad$ /joo::: löysin Hömppälinnan Piipmarketista (.) makso vaan neljä euroa.

Selityksissä tuodaan esiin ostopaikka tai hinta, joista vähintään jompikumpi osoittaa, että kohde on kenen tahansa saatavilla - eikä näin ollen vastaanottajan erityisansio tai -mahdollisuus. Ostopaikan mainitsemisen voi ajatella myös jatkavan joopartikkelilla aloitettua, informaatiopuolta korostavaa linjaa; sillä tarjotaan lisää tietoa kehun kohteesta. Muistiinpanija on muuttanut paikkakunnan ja ostopaikan, mutta hänen valitsemansa peitenimikin, Piipmarket, kertoo, että kyse on isosta kaupasta, jotka ovat tavallisesti edullisia, kaikille tarkoitettuja kauppoja. Hän on myös merkinnyt partikkelin perään kaksoispisteitä (:), jotka merkitsevät äänteen venytystä. Tämä voisi merkitä partikkelin esittämistä varauksellisena, mutta kovin suurta merkitystä sille ei voi antaa, koska katkelma perustuu muistiinpanoon eikä sitä voi toistaa.

Vastaanoton merkkinä dialogipartikkeli nii(n) taas ilmaisee paitsi samanmielisyyttä myös sitä, että vastaanottajan asenne on syntynyt jo aiemmin (Sorjonen 2001: 167, 195). Vahvasti samanmielinen niin on tavallinen kehujen vastaanotin, mutta sen käyttämisen lisäksi puhuja osoittaa, ettei kehu ole hänen ansiotaan. Tätä kuvaa seuraava esimerkki, jossa Ella ja Taimi puhuvat puhelimessa ja Ella kehuu Taimin sitkeää luonnetta (r. 1-2).

(20) Valosa luonne [SKL; sg 142 aO2)

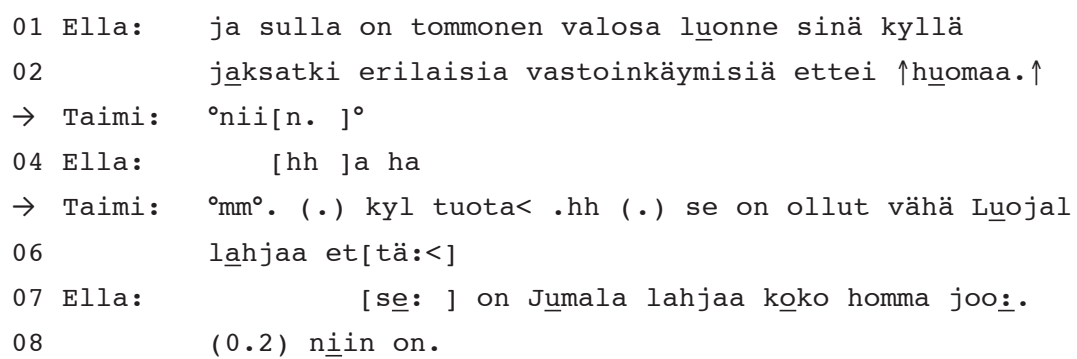

Taimi vastaanottaa Ellan kehun samanmielisellä niin-partikkelilla (r. 3). Leksikaalisella tasolla tämäkin niin merkitsee tiedon jo puhujalle tutuksi. Myös partikkelin intonaatio vaikuttaa kuitenkin sen tulkintaan. Tässä partikkeli on lausuttu melko 
hiljaa ja sitä seuraa välittömästi selitys (r. 3 ja 5-6) - hyväksymisen ja selityksen väliin jää vain Ellan hyvin lyhyt naurahdus (r. 4). Selitys tarjoaa myönteiselle ominaisuudelle syyn, johon Taimilla ei itsellään ole ollut osuutta eikä se ole hänen ansionsa. Selitykseen yhtyy myös kehuja, ja naiset pääsevät näin myös vahvistamaan yhteistä arvomaailmaansa.

Olemme tässä luvussa esittäneet, kuinka suomalaisessa keskustelussa kehut pääasiassa hyväksytään, mikä näyttää sotivan itsekehun välttämisen vaateen kanssa. Tämä potentiaalinen ongelma ratkaistaan niin, että kehu sekä hyväksytään että osoitetaan joksikin, mikä ei ole kehun kohteen ansio - tässä järjestyksessä. Järjestys kuvaa vastaanottajan suhdetta kahteen erilaiseen odotukseen, samanmielisyyteen eli kehujen tapauksessa toisen mielipiteen kunnioittamiseen ja toisaalta itsekehun välttämiseen.

\section{Kehun paikka ja tehtävät}

Golato (2005) korostaa kehun sekventiaalisen paikan merkitystä: analyysin on käsiteltävä myös sitä, millaisen toimintajaksojen yhteydessä kehu esitetään ja mitä se tekee juuri tuossa keskustelun kohdassa (mt. luku 4). Tällaisella tarkastelulla voi selvitä esimerkiksi se, että kehuva lausuma voi samalla tehdä muutakin (esim. kehua yhtä mutta kritisoida toista) ja että kehut liittyvät systemaattisesti tiettyihin puhetoimintoihin (esim. kiittämiseen tai kieltäytymiseen). Edellisissä luvuissa on jo nähty monia kehun konteksteja: kehu voi syntyä vaikkapa kehujan tekemästä vastaanottajan vaatteita koskevasta huomiosta (esim. 3 ja 17). Tässä luvussa tarkastelemme muutamia sellaisia konteksteja, joissa kehumiseen näyttäisi liittyvän strategisia puolia.

\subsection{Kehuminen ja pyytäminen}

Usein kehuja varmasti esitetään pyyteettömästi: kehutaan ruokia ja vaatteita, kun ne ovat hyviä ja kivoja. Kehua voidaan myös kohteliaisuudesta, kun tiedetään, että kehuminen on tilanteessa odotuksenmukaista. Puhuja voi kuitenkin käyttää kehua myös strategisesti edistääkseen jotakin omaa asiaansa. Tarkastelemme asiaa yhden puhetoiminnon, pyytämisen, kautta.

Pyytämistä pidetään vuorovaikutuksellisesti ongelmallisena toimintona (kokoavasti ks. Curl \& Drew 2008). Keskustelunanalyyttisessä tutkimuksessa on esitetty, että pyytäminen ja tarjoutuminen muodostavat toimintoparin, jossa tarjoutuminen tai tarjoaminen on preferoitu ja pyytäminen preferoimaton vaihtoehto (ks. esim. Schegloff 2007: 82-86)." Puhuja, joka haluaisi jotakin, voikin pyrkiä toimimaan niin, että tarjoutumiselle avautuu paikka eikä suoranaista pyyntöä tarvitse edes esittää. Golato (2005) käsittelee kehun esittämistä yhtenä tällaisena strategiana: jos puhuja esimerkiksi kehuu

11. Ajatus pyynnön ja tarjoutumisen preferenssisuhteesta on esitetty useissa tutkimuksissa (esim. Schegloff 1979: 49; Lerner 1996; Golato 2005; Taleghani-Nikazm 2006), mutta sitä on myös kritisoitu (Curl \& Drew 2008). 
ruokaa, se voidaan käsittää osoitukseksi halusta saada sitä lisää. Mutta kehun ja pyynnön suhde näyttäytyy myös toisenlaisena. Aineistossamme on joukko tapauksia, joissa puhuja käyttää kehua pyynnön alustuksena ja perusteluna. Esimerkissä 21 kehu on laadittu pyynnön perusteluksi. Saara on soittanut Ellalle ja ilmaisee rivillä 3 aikovansa kysyä neuvoa; tervehdykset on juuri vaihdettu.

(21) Neuvoa viisaalta [SKL; sg 142 2a2]

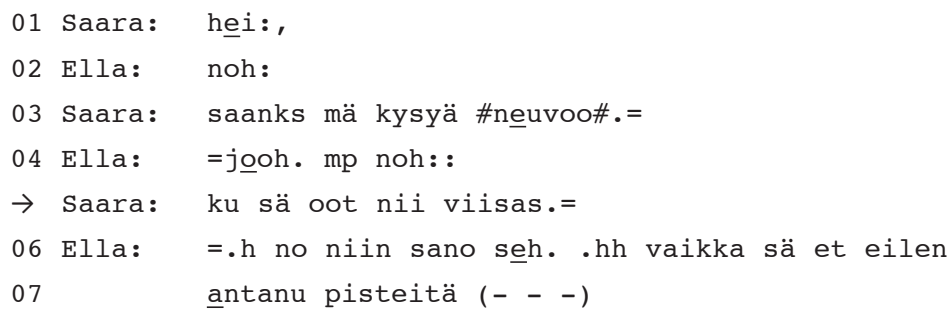

Pyynnön ongelmallisuus näkyy siinä, miten asiaan mennään johdattelevien jaksojen kautta (esisekvensseistä ks. Schegloff 2007: luku 4): ensin huomionkohdistimella, sitten jatkokehotuksen jälkeen pyynnöllä kysyä neuvoja (r. 1 ja 3) ja lopulta perustelulla ( $k u$-partikkeli, ks. Herlin 1998). Perustelu sisältää kehun (sä oot niin viisas).

Kehu toimii pyynnön perusteluna myös seuraavassa tapauksessa. Siinäkin pyydettävän asian (remonttiapuna toimiminen) ja kehuttavan ominaisuuden (vahvuus) välinen suhde on selkeä. Esimerkin 22 puhelussa on kolme puhujaa samanaikaisesti linjalla: Tarulla on meneillään iso remontti, josta on jonkin aikaa puhuttu (katkelmaa käsitelty myös esimerkkinä 6). Ennen katkelmaa Taru on alkanut implikoida avun tarvetta ja lopulta esittää Arton mahdollisena auttajana (r. 4-5).

(22) Vahva mies [SKL; sg 6 1A1]

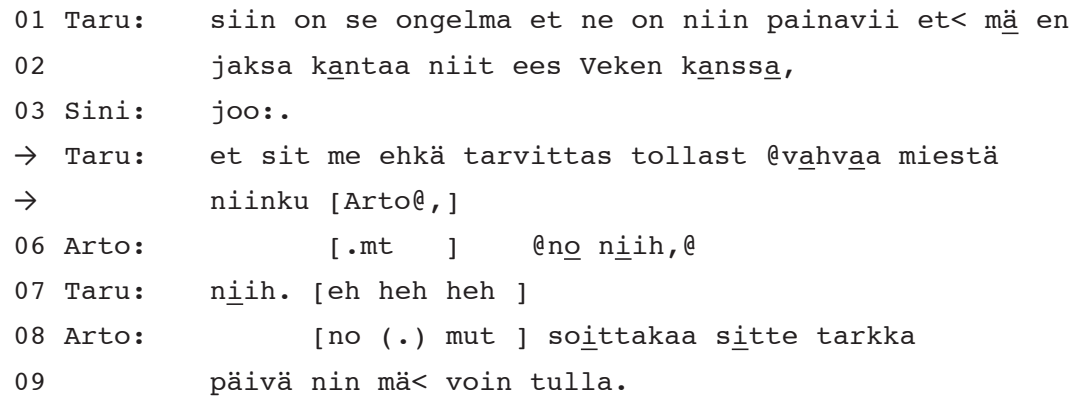

Vuoro sisältää upotetun kehun: Artoa kuvataan vahvaksi mieheksi (r. 4). Huomiota kiinnittää se, että juuri tämän kehuvan osan vuorosta Taru tuottaa erityisellä äänensävyllä (merkitty litteraatioon @-merkeillä). Näin osa nousee vuorossa kohosteiseksi (vrt. Haakana \& Visapää 2005) ja mieltyy sävyltään leikilliseksi. Tulkintamme mukaan Taru ottaa käyttöön stereotyyppisen keimailevan puhetavan: hän leikillisesti aktivoi 
vastakkainasettelun vahva mies - heikko nainen. Muutos juuri tässä kohtaa voi liittyä myös siihen, että Taru tajuaa toimintansa ongelmallisuuden: leikittelevä prosodia voi olla vihje siitä, että puhuja tiedostaa käyttävänsä tunnistettavaa vuorovaikutuskeinoa, kehumista pyynnön palveluksessa.

Esimerkeissä 21 ja 22 kehuminen on rakennettu pyynnön perusteluksi. Kehuilla voi nähdä niissä kuitenkin muitakin tehtäviä: positiivisina toimintoina niillä lievennetään pyytämisen ongelmallisuutta; pyytäjä haluaa vastaanottajalta jotakin, mutta myös antaa tälle jotakin - myönteisen arvion. Samanlainen funktio voidaan nähdä myös esimerkissä 23 (edellä myös esim. 10). Siinä pyynnön ja kehun suhde on kuitenkin erilainen - ne kohdistuvat eri asioihin, eikä kehu toimi pyynnön perusteluna. Soittajana on pappilan emäntä, Ella, joka on värväämässä Arjaa kahvia kaatamaan seurakunnan tilaisuuteen. Ella ei kuitenkaan esitä pyyntöä heti vaan aloittaa kehumalla Arjan lukemista aiemmassa seurakunnan tilaisuudessa.

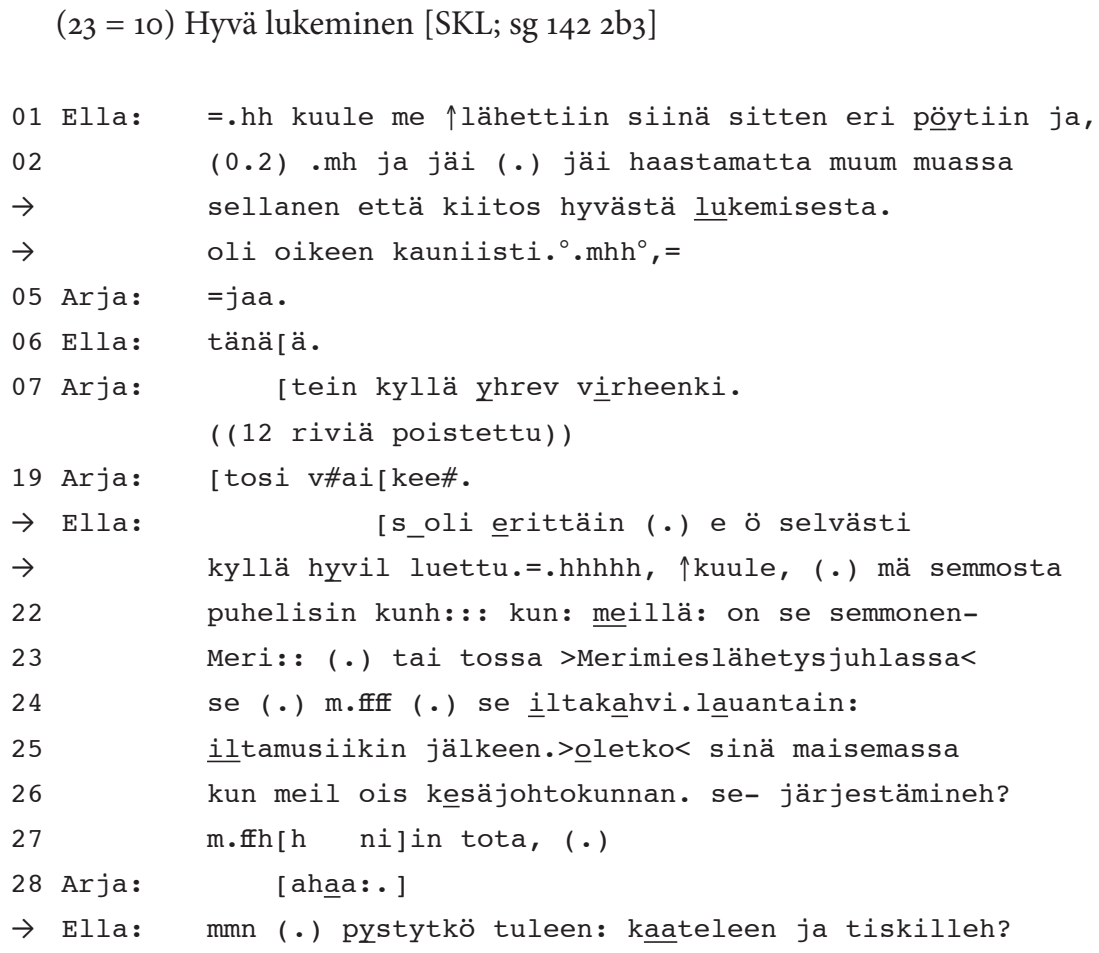

Ella nostaa ensimmäiseksi puheenaiheeksi aiemmin sanomatta jääneen asian (r. 1-), kiittää Arjaa. Kiitos sisältää kehuvan adjektiivin hyvä, ja kehuminen jatkuu seuraavassa lausumassa (oli oikeen kauniisti). Jo tässä vaiheessa Ella implikoi, että kehuminen ei ole kuitenkaan ainoa asia, joka on jäänyt puhumatta (r. 2 muum muassa). Vastaanottojakso muodostuu tässä pitkähköksi, ja Ella sulkee jakson palaamalla kehuun (r. 20-21). Siitä hän siirtyy nopeasti seuraavaan asiaan, pyynnön esittämiseen. Tässä katkelmassa kehu ja pyyntö ovat siis toisistaan erilliset; tässäkin kehu kuitenkin valmistaa maaperää tulossa olevalle hankalammalle toiminnolle. 
Edeltävät esimerkit osoittavat, että pyynnön esittäjä voi käyttää kehua pyynnön ongelmallisuutta lieventävänä toimintona. ${ }^{12}$ Golaton (2005) tutkimuksessa ei käsitellä pyyntöjä, mutta kylläkin muita hankalia toimintoja, joiden yhteydessä kehuja käytetään (esim. kutsusta tai tarjouksesta kieltäytyminen). Yleisempänä tendenssinä näissä voi siis nähdä sen, että ongelmallisen puhetoiminnon tekemistä lievennetään positiivisella toiminnolla (ks. myös Watts 2003: 129; Svinhufvud 2011).

\subsection{Kehujen kalastelu}

Joidenkin aineistomme kehujen kohdalla syntyy vaikutelma, että kehuttava on edellä toiminut niin, että kehu on odotuksenmukainen seuraava teko. Tällöin voisi puhua kehun "kalastelusta"; esimerkiksi Golato (2005: 108) mainitsee tällaisen ilmiön. ${ }^{13}$ Kehujen kalasteluun liittyy tietty intentionaalisuus ja strategisuus: puhuja "haluaa" - tietoisesti tai tiedostamattaan -, että häntä kehutaan, ja laatii toimintansa sen mukaisesti. Keskustelunanalyyttisesti tällaisen asian osoittaminen on hyvin hankalaa - puhujien pään sisään ei päästä, eikä sitä yritetäkään. Neutraalimmin ilmiötä voi kuvata sanomalla, että tietynlaiset puhetoiminnot näyttävät aktivoivan kehun relevantiksi seuraavaksi toiminnoksi.

Selkeästi tunnistettavissa oleva kehunkalastelustrategia näyttää olevan puhujan esittämä itsekritiikki. Pomerantz (1984) on osoittanut, että englanninkielisissä keskusteluissa kaikki kannanotot eivät tee relevantiksi samanmielisyyden osoitusta; itsekriittisiin, itseä vähätteleviin kannanottoihin on preferoitua vastata erimielisesti. Vastaukset voivat olla eri tavoin erimielisiä, mutta usein ne sisältävät vastaanottajaan kohdistuvan myönteisen arvion (mas. 85). Aineistossamme on muutama tällainen tapaus. Seuraavat esimerkit liittyvät puhujan ulkonäköön. Esimerkki 24 on muistiinpano, ja siinä puhujan A vuorot riveillä 1 ja 3 implikoivat, että hänellä on mahdollisesti liikaa meikkiä - ja jatkossa hän väittää itseään myös läskiksi (r. 8-9).

(24) Baarissa [muistiinpano; 27-vuotiaat naiset, jotka ovat hyviä ystäviä. Ollaan baarissa myöhäisillasta ja odotetaan paikalle A:n seuralaista. A ja B ovat poistuneet vessaan ehostautumaan. A on huolissaan ulkonäöstään.]

o1 A: onks mul liikaa meikkiä?

O2 B: no ei tosiaan

o3 A: mutku se ei selvästi tykkää et naisel on paljo meikkiä.

04 B: no ei oo. sä näytät tosi hyvältä (tauko) Just tolleen paljon mut

05 vaaleita värejä ni miehethän ny ei tajuu kauan tota on menny laittaa

o6 A: (naurahtaa) nimenomaan. Ei ne tajuu mikä niihin iskee.

07 B: Nii ja sinähän kyllä isket (nauraa)

12. Kehujen käyttöä pyytämisessä ei ole aiemmassa tutkimuksessa analysoitu, mutta ilmiön tunnistettavuudesta kertoo se, että monissa kohteliaisuustutkimuksissa se kuitenkin esiintyy ohimennen esitetyn maininnan tai keksityn esimerkin tasolla (ks. esim. Brown \& Levinson 1987: 103; Watts 2003: 61, 88-89; Mills 2003: 219-221).

13. Kehujen kalastelua ei kuitenkaan tietääksemme ole varsinaisesti tutkittu. 


$\begin{array}{lll}08 & \text { A: } & \text { (nauraa) juu minä isken ku sika limppuun. Ei mut ihan tosi mä } \\ \text { o9 } & \text { näytän läskiltä } \\ 10 & \text { B: } & \text { lopeta! nyt vittu lopeta } \\ 11 & \text { A: } & \text { mut ei se tykkää musta. se kuitenki ihastuu suhun } \\ 12 & \text { B: } & \text { joopa joo. sä näytät ihan vitun hyvältä ja nyt lopetat }\end{array}$

B kieltää meikin liiallisuuden (r. 4-5) ja vahvistaa vuoroaan A:n ulkonäön kehumisella (sä näytät tosi hyvältä). Riveillä 8-9 A kritisoi edelleen ulkonäköään (mä näytän läskiltä), johon B reagoi kehotuksella lopettaa itsekritiikki - ja kenties myös kehujen kalastelu. B edelleen kehottaa (r. 12) A:ta lopettamaan itsensä haukkumisen ja tuottaa myös A:n ulkonäköä kehuvan lausuman. Puhujan itsekriittiset lausumat saavat siis systemaattisesti aikaan kehuja (ja myös vahvan vastustelevia reaktioita). Myös seuraavassa muistiinpanossa puheena on ulkonäkö. Siinä esiintyy paitsi itsekritiikkiä myös toisen osallistujan kehumista, joka sekin voi olla tapa hakea itseen kohdistuvaa kehua.

(25) Tyyli [muistiinpano; Puhujat A ja B hyviä ystäviä, n. 30- ja 35-vuotiaita naisia. Keskustelu käydään, kun ollaan pukeutumassa ja lähdössä yhdessä iltaa viettämään. Kehun kohteena B:n vaatteet.]

o1 A: apua mä en kyllä kestä. sä oot niin tyylikäs. mua kyllä harmittaa O2 tää mun vaatevalinta.

03 B: no emmä tiedä (.) mun mielestä toi väri (A:n paidan väri) sopii 04 sulle. se oot ihan ku yökerhoon lähdössä. mulla on tämmönen 05 täti-look.

Riveillä 1-2 A kehuu B:n tyylikkyyttä ja käsittelee omaa vaatevalintaansa ongelmallisena (mua harmittaa). Tähän B vastaa kehumalla A:n paitaa ja toisaalta taas vähättelemällä omaa vaatetustaan (täti-look, r. 5). Kumpikin siis kehuu toisen asua ja vähättelee omaansa, ja katkelmassa yhdistyykin kaksi kehun kalastelun tapaa: itsekritiikki ja toisen kehuminen. Joihinkin kehuihin reagoidaan myös vastakehulla, joten kehun tuottaminen voi näin antautua myös strategiseen käyttöön: toisinaan puhekumppanin kehumisen taustalla voi siis olla mahdollisuus siitä, että kehu kohdistuu seuraavaksi ensimmäiseen kehujaan.

Edelliset esimerkit ovat näyttäneet muutamia sellaisia kielellisiä toimintoja, joihin reagoidaan kehulla: itsekritiikki ja kehuminen. Muitakin sellaisia toimintoja on olemassa, esimerkiksi jonkin tyypillisesti kehunarvoisen asian topikalisoiminen (esim. 28) ja arvioita hakevan kysymyksen esittäminen (esim. 29). ${ }^{14}$ Seuraavassa Jaana esittelee vierailleen perinnönjaossa saamiaan esineitä. Hän esittelee niitä yksitellen, ja useaan tällaiseen esineen topikalisointiin reagoidaan kehulla:

14. Erilaisia kehun kalastelustrategioita käsitellään myöhemmin eri julkaisussa. 
(26) Glögi [SKL; sg 355]

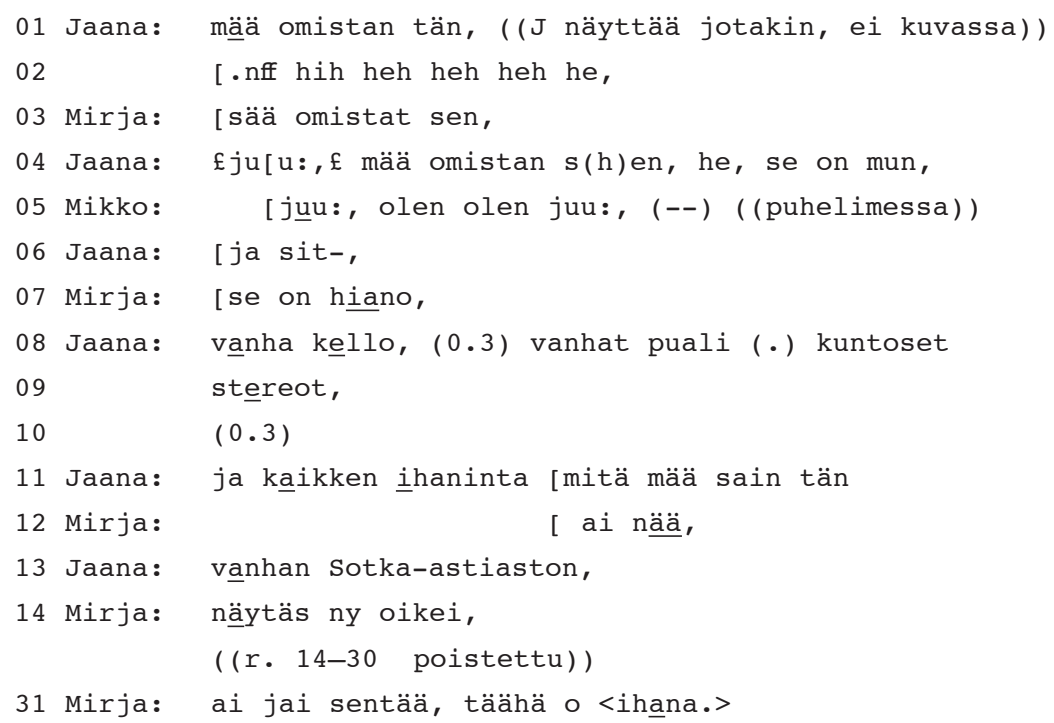

Jaana viittaa johonkin esineeseen (r. 1) demonstratiivipronominilla tää (Jaana ja esine eivät näy videolta) ja kertoo nyt olevansa esineen omistaja. Mirja vastaa kehulla (r. 7). Jaana listaa muita saamiaan esineitä (r. 8-9) ja nostaa esiin Sotka-astiaston (r. 13); sen esittelyssä hän käyttää myönteistä luonnehdintaa (kaikkein ihaninta). Mirja pyytää astioita katsottavaksi (r. 14) ja hetken kuluttua esittää päivittelevän kehun (r. 31 ai jai sentää, täähä o ihana). Tässä tilanteessa kehut tuntuvat selkeästi kutsutuilta; Jaana esittelee perintökalleuksiaan uuden omistajan ylpeydellä.

Kuten sanottu, usein on vaikea analyyttisesti osoittaa, että puhuja nimenomaan hakisi kehuja esimerkiksi kritisoidessaan itseään tai esitellessään uutta omaisuuttaan. Tarkastelemme lopuksi esimerkkiä, jossa on vahva kalastelun tuntu - ja jossa tämä kalastelu lopulta myös eksplikoidaan. Tulkinnan vahvuus syntyy myös siitä, että keskustelussa esiintyy peräkkäin monia tapoja hakea kehua. Katkelma on kahden naisen, Tainan ja Leenan, keskustelusta ja lähtee liikkeelle Leenan parisuhdeongelmista. Taina on topikalisoinut asian kysymällä, miltä Leenasta tuntuu. Jakso on pitkä, ja tässä voidaan näyttää vain sen loppu (aineistosta ja jakson analyysista tarkemmin ks. Haakana 1993), jossa Taina hakee Leenalta itseään koskevaa arviota. Sitä ennen on tapahtunut seuraavaa:

i) Leena on kertonut huolistaan

ii) Taina on kehunut Leenan asennetta (optimismi, valoisan tulevaisuuden näkeminen)

iii) ja siirtynyt siitä itsensä kritisointiin: hän ei näe valoisaa tulevaisuutta vaan maalaa vain taivaanrantoja jne. Taina myös esittää toiveen, että kehittyisi valoisampaan suuntaan. 
Näiden vaiheiden aikana Leena ei arvioi Tainaa: hän pitää itsensä puheenaiheena ja suhtautuu lisäksi humoristisesti ja kiusoitellen Tainan vakaviin puheenvuoroihin. Seuraavaksi Taina siirtyykin kysymään suoraan Leenalta itseään koskevaa arviota. Katkelman 27 alussa Taina asettaa Leenan asemaan, josta tämän pitäisi pystyä arvioimaan Tainan muutosta (r. 1-4 ku sä oot näin monta vuotta mut tuntenu). Tähänkin vuoroon Leena vastaa ensin humoristisesti: vastaus on epäodotuksenmukaisen suora kritiikki (r. 5 pahempaan menee koko ajan), ja se on merkitty äännelaadun muutoksella ja naurulla vitsailevaksi. Pitkähkön leikittelyjakson jälkeen Leena kuitenkin palaa vastaamaan vakavasti Tainan esittämään kysymykseen (r. 51-56). Vuoron voi kuulla arvioivan Tainan muuttuneen positiiviseen suuntaan.

(27) Muutos

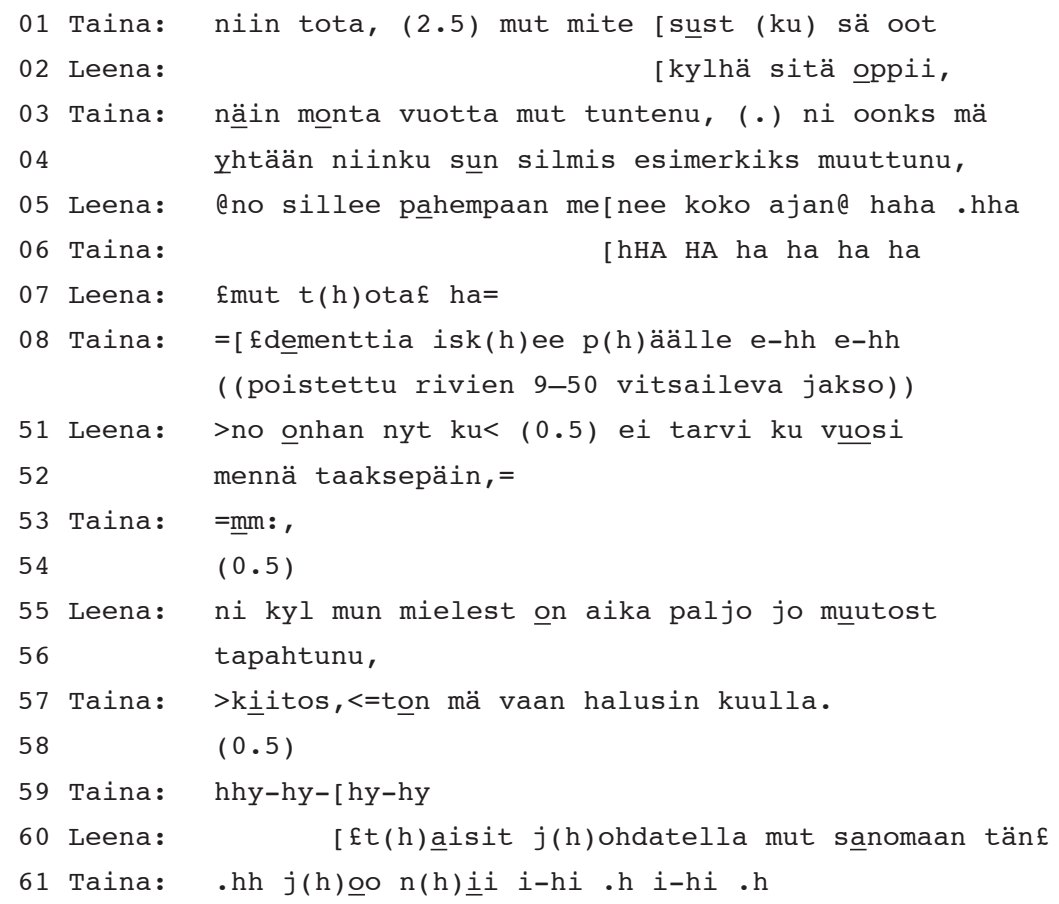

Leenan vakava vastaus (r. 51-) luonnehtii Tainan kehitystä myönteisesti: muutosta on tapahtunut jo aika paljon. Mutta onko tämä lausuma kehu? Tuntumamme siis on, että tässä pitkässä puheenjaksossa Taina oli kalastelemassa itseensä kohdistuvaa kehua ja pohjusti sitä monin tavoin: kehui ensin Leenaa vastaavasta asiasta (asenne, selviytymiskyky), siirtyi sitten kritisoimaan itseään ja lopulta haki itseensä kohdistuvaa arviota kysymällä. Sekventiaalisesti se onkin vastaus Tainan kysymykseen - ja vieläpä myöhään tuleva toinen vastaus, joka esitetään vasta vitsailevan ensivastauksen jälkeen. Jonkinlaisesta kehun kalastelusta tässä lienee ainakin kyse, ja tämän Taina myös eksplikoi (r. 57). Vuoro alkaa kiitos-sanalla, joka sopisi kehun vastaanotoksi, ja sen jälkiosa ton mä vaan halusin kuulla osoittaa, että Tainalla oli edellisissä toimissaan taka-ajatus. 
Vuoro osoitetaan jälkikäteen naurulla (r. 59) humoristiseksi, ja Leena menee mukaan tähän huumoriin eksplikoimalla Tainan toiminnan suunnitelmallisuuden (taisit johdatella mut sanomaan tän r. 60). Naiset eksplikoivat yhteistuumin edeltävän puhejakson johdattelevuuden ja kalastelevuuden.

Kehun kalastelu on siis ilmiö, joka voidaan keskustelussa joskus eksplikoidakin. Kalastelu mielletään usein ongelmalliseksi; se koetaan ärsyttäväksi. Eri asia tietysti on, tuodaanko tuo ärsyyntyminen esiin - ja miten. Internetin keskusteluissa kalastelua pidetään usein asiana, johon "syyllistytään". Esimerkissä 24 (s. 482-483) puhuja kehottaa toista lopettamaan itsekritiikin (ja ehkä kehujen kalastelun), ja viimeisessä esimerkissä Leenan toiminnan (vitsailu, kiusoittelu jne.) voi kuulla vastustavan toisen puhujan toimintaa. Joskus kuulee puhujan myös sanovan, että hän ei kalastele kehuja, vaikka toiminta (esim. itsekritiikki) voi sellaiselta vaikuttaakin. Tällaisia "en kalastele kehuja"lausumia löytää myös esimerkiksi Internetin keskustelupalstoilta.

\section{Lopuksi}

Suomalaiset kehut ja niiden vastaanotto voivat saada erilaisia muotoja ja tulkintoja: muuttujina ovat esimerkiksi kehun kohde, kehujan ja kehuttavan suhde ja konteksti, jossa kehut tuotetaan. Olemme artikkelissamme tuoneet tätä variaatiota esiin ja osoittaneet, että kehumisessa on paljon vaihtelua: kehuja esitetään erilaisin rakentein, ne voidaan kohdistaa erilaisiin asioihin (puhujan luonne, toiminta, ulkonäkö jne.), kehuja otetaan vastaan erilaisin kielellisin keinoin ja kehut esiintyvät erilaisissa toimintakonteksteissa. Variaation lisäksi aineisto kuitenkin osoittaa myös toistuvuutta niin rakenteen, vastaanoton kuin kontekstien suhteen.

Kehuja esitetään toistuvasti samanlaisin rakentein, joista yleisimpiä ovat kopulaja omistuslause. Toinen toistuva piirre suomalaisten kehujen rakenteessa on se, että niissä on harvemmin viittauksia kehujaan tai kehuttavaan. Silloin kun kehuissa on ensimmäisen tai toisen persoonan viittauksia, neuvotellaan kehujen välityksellä osallistujien välisistä suhteista tai vastataan itsekritiikkiin tai huoltenkerrontaan. Persoonien esiin nostamiselle löytyy siis kontekstuaalinen motivaatio. Se, että puhuja harvemmin viittaa itseensä kehulausuman sisällä, osoittaa, että suomalainen kehu rakennetaan näennäisen objektiiviseksi tosiasiaksi. Vaikka kehujen kielellinen rakenne on osittain hyvinkin konventionaalinen, aineistomme myös osoittaa, että kehun kielellinen rakenne on monin tavoin sidoksissa esimerkiksi siihen, minkälaisessa toimintaympäristössä kehuva lausuma esiintyy ja mitä kehulla tehdään: kehulausuman ja vuoron rakenteellinen monimutkaisuus ilmentää useimmiten meneillään olevan toiminnan monikerroksisuutta.

Kehun vastaanottamista pidetään usein hankalana: pitääkö vastaanottajan hyväksyä kehu, ottaa se kursaillen vastaan vai kieltää kehu kokonaisuudessaan? Aineistomme osoittaa, että vaikka kehuja otetaan vastaan kaikilla edellä mainituilla tavoilla, pääosa kehuista hyväksytään. Lisäksi vastaanottaja osoittaa usein myös jo itse ajatelleensa asiaa ja päätyneensä samanlaiseen myönteiseen arvioon kuin kehuja. Tämä piirre viittaa siihen, että suomalaisissa vastaanotoissa tärkeä tavoite on pyrkimys samanmielisyyteen. 
Pyrkimys itsekehun välttämiseen tulee toisena ja näkyy selityksenä; muuten kehun voimakas hyväksyntä voisi synnyttää tulkinnan itsekehusta, jota usein pidetään ongelmallisena.

Kehut esiintyvät toistuvasti tietynlaisissa konteksteissa, ja niillä näyttää olevan myös säännönmukaisia käyttöjä muiden puhetoimintojen ohessa. Konteksti, jossa kehuja on pyytämässä jotakin kehun vastaanottajalta, on yksi kehun paikka ja pyynnön valmistelu sen tehtävä - kehu näyttää toimivan ongelmallisen puhetoiminnon lieventäjänä. Kehuja voidaan myös kalastella. Kehu voidaan esittää sellaisessa kontekstissa esimerkiksi juhlissa -, jossa vastakehu on sosiaalisesti odotuksenmukaista. Esimerkiksi uusia tavaroita voidaan myös esitellä tai itseä moittia kehun saamisen toivossa. Tällaisessa kehun kalastelussa on kuitenkin riski, että tuloksena on paitsi kehuja myös ärtymystä. Kalastetun kehun aitous on myös epävarma. Usein kehu aloittaa kokonaan uuden puhejakson, mutta kalasteltu kehu tulee vuorovaikutuksellisesti toisen toiminnan paikalle: se voi olla esimerkiksi vastaus kysymykseen. Kehuna se on varsin toisenlainen kuin spontaanisti annettu.

Kehumiseen tiivistyy monia ihmissuhteiden keskeisimpiä kysymyksiä. Vaikka kehuminen on perustaltaan myönteistä, toimintana se on aina myös arvioimista. Kehuminen voi kertoa keskustelukumppaneiden läheisestä suhteesta, jossa annetaan toiselle lämmintä positiivista palautetta. On kuitenkin puhuttu myös kehujen ongelmallisemmista puolista: esimerkiksi Holmes (1995) myöntää, että kehuilla on "pimeämpi" puolensa. Kehuja voidaan kalastella tai käyttää välineenä muiden toimintojen tekemiseksi. Kyse ei aina olekaan erityisesti kohteliaisuudesta, vaan keskustelukumppaneiden välisten, usein monimutkaisten suhteiden neuvottelusta. Monet kehuista syntyvät kuitenkin usein spontaanisti ja varmastikin ilman taka-ajatuksia: kehutaan keskustelukumppanin vaatetta, koska se on hieno, tai tämän valmistamaa ruokaa, koska se on hyvää.

\section{Lähteet}

Brown, Penelope - Levinson, Stephen 1987: Politeness. Cambridge: Cambridge University Press.

Byrnes, Heidi 1986: Interactional style in German and American conversations. - Text $6 \mathrm{~s}$. $189-206$.

Curl, Traci S. - Drew, Paul 2008: Contingency and action. A comparison of two forms of requesting. - Research on Language and Social Interaction 41 s. 129-153.

Drew, PAUl 1991: Asymmetries of knowledge in conversational interactions. - Ivana Markova \& Klaus Foppa (toim.), Asymmetries in dialogue s. 21-48. Hertfordshire: Harvester Wheatsheaf.

Gathman, E. Cabell Hankinson - Maynard, Douglas W. - Schaeffer, Nora CATE 2008: The respondents are all above average. Compliment sequences in a survey interview. - Research on Language and Social Interaction 41 s. 271-301.

Golato, Andrea 2005: Compliments and compliment responses. Grammatical structure and sequential organization. Amsterdam: Benjamins.

HAAKANA, MARKKU 1993: Vakavaa ja ei-vakavaa puhetta. Huumorin ja vakavan kategorioista eräässä arkikeskustelussa. Pro gradu -tutkielma. Helsingin yliopiston suomen kielen laitos. 
1999: Laughing matters. A conversation analytical study of laughter in doctor-patient interaction. Helsinki: Helsingin yliopiston suomen kielen laitos.

HaAkana, Markku - VisapäÄ, Laura 2005: Tuttu tv:stä. Fakta homman äänet keskustelun keinona. - Markku Haakana \& Jyrki Kalliokoski (toim.), Referointi ja moniäänisyys s. 249-269. Helsinki: Suomalaisen Kirjallisuuden Seura.

Halonen, Mia 2010: Compliment responses in Finnish everyday conversations. Orienting to two contradictory expectations. Esitelmä konferenssissa International Conference on Conversation Analysis 4.7.2010. Mannheim.

HARREN, INGA 2001: @Ne?@ in Alltagesprächen. Interaktive Funktionen und Positionierung in Turn und Sequenz. MA-tutkielma. Universität Oldenburg.

Helasvuo, Marja-Liisa 2006: Passive. Personal or impersonal? A Finnish perspective. Marja-Liisa Helasvuo \& Lyle Campbell (toim.), Grammar from the human perspective. Case, space and person in Finnish s. 233-255. Current Issues in Linguistic Theory 277. Amsterdam: John Benjamins.

Herbert, Robert K. - Straight, H. Stephen 1989: Compliment-rejection versus compliment-avoidance. Listener-based versus speaker-based pragmatic strategies. - Language \& Communication 9 s. 35-47.

Heritage, John 1996 [1984]: Harold Garfinkel ja etnometodologia. Suomentaneet Ilkka Arminen, Outi Paloposki, Anssi Peräkylä, Sanna Vehviläinen \& Soile Veijola. Helsinki: Gaudeamus.

2002: Oh-prefaced responses to assessments. A method for modifying agreement/disagreement. - Cecilia A. Ford, Barbara Fox \& Sandra A. Thompson (toim.), The language of turn and sequence s. 196-224. New York: Oxford University Press.

Heritage, John - RAymond, Geoffrey 2005: The terms of agreement. Indexing epistemic authority and subordination in talk-in-interaction. - Social Psychology Quarterly $68 \mathrm{s.}$ 15-38.

Herlin, Ilona 1998: Suomen kun. Suomalaisen Kirjallisuuden Seuran Toimituksia 712. Helsinki: Suomalaisen Kirjallisuuden Seura.

Holmes, JANET 1995: Women, men and politeness. London: Longman.

Holmes, Janet - Brown, Dorothy F. 1987: Teachers and students learning about compliments. - TESOL Quarterly 21 s. 523-546.

Huth, Thorsten 2006: Negotiating structure and culture. L2 learners' realization of L2 compliment-response sequences in talk-in-interaction. - Journal of Pragmatics $38 \mathrm{~s}$. 2025-2050.

ISK = Hakulinen, Auli - Vilkuna, Maria - Korhonen, Rittta - Koivisto, Vesa - Heinonen, Tarja Rittta - Alho, Irja 2004: Iso suomen kielioppi. Helsinki: Suomalaisen Kirjallisuuden Seura.

JEFFERSON, GAIL 1988: On the sequential organization of troubles-talk in ordinary conversation. - Social Problems 35 s. 418-441.

Knapp, Mark L. - Hopper, Robert - Bell, Robert A. 1984: Compliments. A descriptive taxonomy. - Journal of Communication 34 s. 12-32.

Koтthoff, Helga 1989: So nah und doch so fern. Deutshe-amerikanische pragmatische Unterschiede in universitären Milieu. - Informationen Deutsch als Fremdsprache $16 \mathrm{~s}$. 448-459.

Lerner, Gene 1996: Finding face in the preference structures of talk-in-interaction. - Social Psychology Quarterly 59 s. 303-321.

Levinson, Stephen C. 2013: Action formation and ascription. - Jack Sidnell \& Tanya Stivers 
(toim.), The handbook of Conversation Analysis s. 105-130. Chichester, UK: Wiley-Blackwell.

Lin, Chih-Ying - Woodfield, Helen - Ren, Wei 2012: Compliments in Taiwan and Mainland Chinese. The influence of region and compliment topic. - Journal of Pragmatics 42 s. 1486-1502.

Mills, SARA 2003: Gender and politeness. Cambridge: Cambridge University Press.

Ochs, Elinor - Schieffelin, BAmbi 1989: Language has a heart. - Text 9 s. 7-25.

Pomerantz, Anita 1978: Compliment responses. Notes on co-operation of multiple constraints. - Jim Schenkein (toim.), Studies in the organization of conversational interaction s. 79-112. New York: Academic Press.

- 1984: Agreeing and disagreeing with assessments. Some features of preferred/dispreferred turn shapes. - Maxwell J. Atkinson \& John Heritage (toim.), Structures of social action. Studies in Conversation Analysis s. 57-102. Cambridge: Cambridge University Press.

Raunioma A, Mirka 2007: Stance markers in spoken Finnish. Minun mielestä and minusta in assessments. - Robert Englebretson (toim.), Stancetaking in discourse. Subjectivity, evaluation, interaction s. 221-252. Amsterdam: Benjamins.

Raymond, Geoffrey - Heritage, John 2006: The epistemics of social realtions. Owning grandchildren. - Language in Society 35 s. 677-705.

Rees-Miller, Janie 2011: Compliments revisited. Contemporary compliments and gender. Journal of Pragmatics 43 s. 2673-2688.

SChegloff, EmAnuel A. 1979: Identification and recognition in telephone openings. George Psathas (toim.), Everyday language. Studies in ethnomethodology s. 23-78. New York: Erlbaum.

2007: Sequence organization in conversation. A primer in Conversation Analysis. Volume 1. Cambridge: Cambridge University Press.

Seppälä, Anu - Virkkunen, Anu 1977: Käytös- ja tapatieto. Helsinki: WSOY.

SePpänen, Eeva-Leena 1998: Läsnäolon pronominit. Tämä, tuo, se ja hän viittaamassa keskustelun osallistujaan. Helsinki: Suomalaisen Kirjallisuuden Seura.

Shaw, Rebecca - Kitzinger, Celia 2012: Compliments on a Home Birth Helpline. - Research on Language and Social Interaction s. 213-244.

Sorjonen, MARJA-LeEna 2001: Responding in conversation. A study of response particles in Finnish. Amsterdam: John Benjamins.

Sorjonen, Marja-Leena - Peräkylä, Anssi 2012: Introduction. - Anssi Peräkylä \& Marja-Leena Sorjonen (toim.), Emotion in interaction s. 3-15. Oxford Studies in Sociolinguistics. Oxford: Oxford University Press.

Stivers, Tanya - Mondada, Lorenza - Steensig, Jakob (toim.) 2011: The morality of knowledge in conversation. Cambridge: Cambridge University Press.

Svinhufvud, Kimmo 2011: Varovasti edeten ja taas perääntyen. Opponenttin palautevuoron rakentuminen. - Virittäjä 115 s. 156-192.

TAINIO, LiIs A 1993: Kannanoton tulkinta keskustelussa. Lisensiaatintutkielma. Helsingin yliopiston suomen kielen laitos.

— 1997: Preferenssijäsennys. - Liisa Tainio (toim.), Keskustelunanalyysin perusteet s. 93-110. Tampere: Vastapaino.

Taleghani-Nikazm, Carmen 2006: Request sequences. The intersection of grammar, interaction and social context. Studies in Discourse and Grammar 19. Amsterdam: John Benjamins.

Watts, Richard J. 2003: Politeness. Cambridge: Cambridge University Press. 
Wolfson, Nessa - Manes, John 1980: The compliment as a social strategy. - Papers in Linguistics 13 s. 236-244.

YläNne-McEwen, VirPi 1993: Complimenting behaviour. A cross-cultural investigation. Journal of Multilingual and Multicultural Development s. 499-508.

YuAn, Yi 2002: Compliments and compliment responses in Kunming Chinese. - Pragmatics 12 s. $183-226$.

\section{Liite 1}

Litterointimerkit

$$
\begin{array}{lc}
\begin{array}{l}
\text { Sävelkulku } \\
\text { Prosodisen kokonaisuuden lopussa } \\
\cdot \\
?
\end{array} & \begin{array}{l}
\text { laskeva intonatio } \\
\text { tasainen intonatio } \\
\text { nouseva intonaatio }
\end{array} \\
\text { Prosodisen kokonaisuuden sisällä } \\
\uparrow & \text { sävelkorkeuden nousu } \\
\downarrow & \text { sävelkorkeuden lasku } \\
\text { heti } & \text { (alleviivaus) painotus }
\end{array}
$$

\section{Päällekkäisyys ja tauot}

\section{Puhenopeus ja äänen voimakkuus}

$><\quad$ (sisäänpäin osoittavat nuolet) nopeutettu jakso

$<>\quad$ (ulospäin osoittavat nuolet) hidastettu jakso

e::i (kaksoispisteet) äänteen venytys

${ }^{\circ}$ nyt $^{\circ} \quad$ ympäristöä vaimeampaa puhetta

AHA (kapiteelit) äänen voimistaminen

\section{Hengitys ja nauru}

.hhh sisäänhengitys; yksi h-kirjain vastaa o.1 sekuntia

hhh uloshengitys

.nii (piste sanan edessä) sana lausuttu sisäänhengittäen

he he naurua

j(h)oo suluissa oleva h sanan sisällä kuvaa uloshengitystä, useimmiten kyse nauraen sanotusta sanasta 


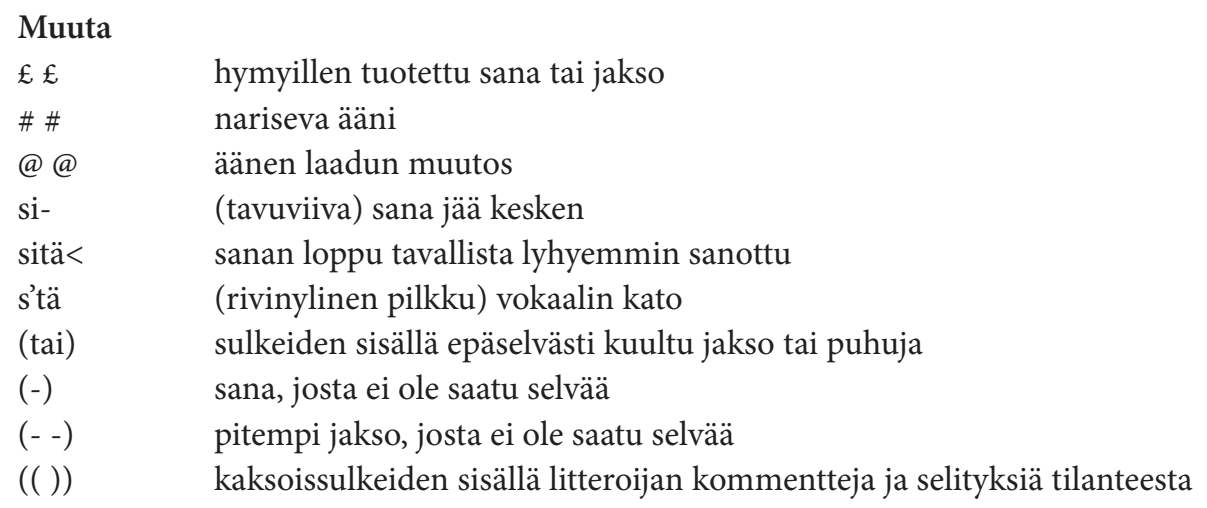

\section{Compliments in everyday Finnish conversation}

The article analyses compliments in everyday Finnish conversation and aims to answer three basic questions: 1) how are compliments constructed on a lexico-syntactic level, 2) how are they responded to, and 3) in what contexts are they used and what functions do they fulfil in these contexts. The study employs the methods of Conversation Analysis, and thus, compliments are analysed as they occur in real contexts, in connection with other conversational actions.

In this study, compliments are defined as positive assessments of the recipient; the compliments can be about several issues - the co-participant's personality, looks, actions in certain situations, or about things in his/her possession (e.g. clothing, apartment). The data comprises both audio-/videotaped naturally occurring conversations (51 compliment sequences) and field notes made by students ( 65 compliment sequences).

Compliments in the data are recurrently presented in simple syntactic structures, copula clauses (e.g. tää on hyvää 'this is good') and verbless descriptions (hyvää piirak$k a a$ 'good pie') being the most frequent among them. Thus, the structure of a compliment is often quite conventionalised and formulaic. However, the structure is affected by the conversational context in a variety of ways. Typical of the compliments in Finnish conversation is that they very seldom include explicit reference to the speaker or the recipient. When ${ }^{\text {st }}$-person reference is used, the compliment occurs in a sequence where the interpersonal relationship of the participants is being negotiated, while ${ }^{\text {nd }}$ person references typically occur in 'troubles-telling' sequences. 
Compliments in the data are, for the most part, responded to in an accepting manner, and furthermore, acceptance is often presented in a rather straightforward manner. In addition, the respondent often displays an epistemic stance that shows that $\mathrm{s} / \mathrm{he}$ has already come to the same positive evaluation on her/his own. This indicates that, in Finnish conversations, speakers demonstrate a preference for agreement rather than disagreement. The avoidance of self-praise is also present in the compliment responses, but it comes second in relation to the expression of agreement. The tendency towards an avoidance of self-praise is manifested in different kinds of accounts featured in the compliment responses.

Compliments in the data occur in a wide variety of contexts, and often seem quite spontaneous. In addition, there are various contexts in which the occurrence of compliments is conventionalised: they are produced when eating food prepared by the hosts of a dinner, when noticing a new piece of clothing on the co-conversationalist, when first visiting a friend's new flat, etc. The data also reveals that compliments can be systematically used in favour of other conversational actions, such as requests. Compliments can be used as a device to make requesting a smoother action. Furthermore, on some occasions, compliments are produced as a response to some prior action (e.g. self-deprecating assessments, topicalisation of a possibly compliment-worthy issue or assessment-seeking questions). In some of these contexts, the first speaker can be seen as 'fishing' for a compliment.

\section{Keskustelukumppanin kehuminen suomalaisessa keskustelussa}

Artikkelissa tarkastellaan suomalaisen arkikeskustelun kehuja kolmen peruskysymyksen kautta: 1) millaisia kehut ovat rakenteeltaan, 2) miten kehut otetaan vastaan ja 3) millaisissa tilanteissa kehuja esitetään ja mitä niillä tehdään? Tutkimus on metodiltaan keskustelunanalyyttinen: kehuja analysoidaan osana aitojen keskustelujen toiminnallista kudosta. Kehu määritellään tutkimuksessa vastaanottajaan tavalla tai toisella kohdistuvaksi myönteiseksi arvioksi. Kehu voi arvioida vastaanottajaa monella tavalla: kehuttavana voi olla esimerkiksi puhekumppanin luonne, hänen toimintansa tietyssä tilanteessa tai vaatetus, hiukset tai asunto. Aineistona on sekä nauhoitetuista arkikeskusteluista poimittuja kehusekvenssejä (51) että opiskelijoiden tekemiä kenttämuistiinpanoja (65 sekvenssiä).

Kehuja esitetään toistuvasti samanlaisin rakentein, joista yleisimpiä ovat kopula- ja omistuslause. Vaikka kehujen kielellinen rakenne on osittain hyvinkin konventionaa- 
linen, aineisto myös osoittaa, että kehun kielellinen rakenne on monin tavoin sidoksissa keskustelun paikalliseen kontekstiin: esimerkiksi siihen, minkälaisessa toimintaympäristössä kehuva lausuma esiintyy ja mitä kehulla tehdään. Kaiken kaikkiaan puheaktipersoonia näkyy vältettävän suomalaisissa peruskehuissa. Vaikuttaa siltä, että ensimmäisen persoonan käyttö liittyisi tilanteisiin, joissa tavalla tai toisella käsitellään keskustelijoiden välisiä suhteita; toista persoonaa taas näkyy käytettävän erityisesti huoltenkerrontakonteksteissa.

Kehujen vastaanotoissa on aineiston perusteella olennaista hyväksymisen yleisyys ja hyväksymisen vahvuus. Pääosa kehuista hyväksytään, ja vastaanottaja osoittaa usein myös jo itse ajatelleensa asiaa ja päätyneensä samanlaiseen myönteiseen arvioon kuin kehuja. Tämä piirre viittaa siihen, että suomalaisissa vastaanotoissa pyritään samanmielisyyteen. Pyrkimys itsekehun välttämiseen tulee toisena ja näkyy selityksenä; muuten kehun voimakas hyväksyntä voisi synnyttää tulkinnan itsekehusta, jota usein pidetään ongelmallisena.

Kehut syntyvät usein spontaanisti ja varmastikin ilman taka-ajatuksia: kehutaan keskustelukumppanin vaatetta, koska se on hieno, tai tämän valmistamaa ruokaa, koska se on hyvää. Toisaalta joissakin tilanteissa kehuminen kuuluu asiaan. Aineiston analyysi tuo esiin joitakin tällaisia konventionaalisia tilanteita, esimerkiksi uuden vaatteen tai kampauksen huomaamisen, uuden asunnon näkemisen ja tarjotun ruoan maistamisen. Toisaalta kehuilla näyttää olevan myös säännönmukaisia käyttöjä muiden puhetoimintojen ohessa. Esimerkiksi kehulla voidaan valmistella pyyntöä. Kehuja voidaan myös kalastella: keskustelukumppania voidaan kehua kontekstissa, jossa vastakehu on sosiaalisesti odotuksenmukaista, ja toisaalta esimerkiksi uusia tavaroita voidaan myös esitellä tai itseä moittia kehun saamisen toivossa.

Kirjoittajien yhteystiedot (address):

Marja Etelämäki: etunimi.sukunimi@helsinki.fi

Markku Haakana: etunimi.sukunimi@helsinki.fi

Mia Halonen: etunimi.m.sukunimi@jyu.fi 